\title{
Sixty Years with the Chrysobalanaceae
}

\author{
Ghillean T. Prance ${ }^{1,2}$ \\ ${ }^{1}$ Herbarium, Royal Botanic Gardens, Kew, Richmond TW9 3AE, UK \\ ${ }^{2}$ Author for Correspondence; e-mail: siriain01@yahoo.co.uk \\ Published online: 14 December 2020 \\ (C) The Author(s) 2020
}

\begin{abstract}
A review is given of the studies of Ghillean Prance and associates on the Chrysobalanaceae over the past sixty years. This has focussed on defining the generic boundaries in the family and on monographic work with a worldwide approach to this pantropical family. The importance of field studies for work on monographs and Floras is emphasized. Monographs are still the basis for much work on conservation, ecology and economic botany and are needed as a foundation for molecular studies. The importance of being open to experimenting with new techniques and as a result being willing to change the taxonomy in accordance with new findings is demonstrated and emphasized. The twelve genera of the Chrysobalanaceae at the beginning of this careerlong study have now increased to twenty-eight in order to present a much better monophyletic and evolutionary arrangement based on recent molecular evidence. In particular it was necessary to divide and rearrange the originally large genera Parinari and Licania into a number of smaller segregate genera. All known species were included in a worldwide monograph published in 2003. A brief review of the economic use for the family is given.
\end{abstract}

Keywords Field work · Floras · Generic boundaries · Molecular taxonomy · Monographs · Parinari $\cdot$ Phenetics $\cdot$ Rhabdodendron $\cdot$ Stylobasium

\section{Introduction}

I began to work on the Chrysobalanaceae in 1960 so it is now sixty years since I first started looking at specimens of the genus Parinari from Africa in the Forest Herbarium, Oxford (FHO). My thesis supervisor, Frank White, suggested that this would be a good genus to study for my doctorate. As I have continued to study this family throughout my career, I felt that now is a good time to look at the lessons learned from a long-term study over this interesting period of much progress and change within systematics. This has taken me on a journey from morphology and phenetics to the 
most recent molecular techniques. Perhaps my most important goal here is to show the critical importance of monographic studies. I have been fortunate to work at research institutions that have encouraged such long-term work. When I started work in 1960 the Chrysobalanoideae was generally regarded as a subfamily of the Rosaceae, for example, by Graham (1960) in Kew's Flora of Tropical East Africa. The certainty of familial status and its distance from the Rosaceae were among the earliest conclusions of my doctoral research. This was not really a new discovery as the group was given a family name by Robert Brown in 1818. It is now well established as the family Chrysobalanaceae embedded in the order Malpighiales. The Chrysobalanaceae has turned out to be a good model for monographic and other studies. It has 545 species of trees and shrubs, is pantropical and occurs in many different habitats from lowland to montane and from forest to savanna. This paper is partially biographic but is mainly about the progression of my studies and those of other researchers on the systematics of the Chrysobalanaceae. It is a review of the lessons learned and the necessary changes to the taxonomy as new data became available.

\section{Towards a Doctoral Thesis}

As mentioned above, it was suggested to me that the genus Parinari in Africa would make a suitable topic for a doctoral thesis, and so I began by examining the specimens of that genus in FHO and at Kew. It soon became apparent to me that the species assembled in the genus Parinari were quite diverse and different from each other. The differences used to separate groups of species within Parinari were much greater than most of those used to separate the other genera of Chrysobalanaceae which had been kept apart for almost 200 years. Following the work of Bentham (1840) any species in the family with a bilocular ovary had been lumped together into the genus Parinari. Early in my work it became apparent that the Parinari needed to be divided into several genera based on criteria similar to those for defining other well-established genera of the Chrysobalanaceae. Since Parinari is a pantropical genus this was not just an African problem. After discussion with my supervisor it was decided that the topic of my thesis should be a worldwide review of the generic concepts in the family rather than a study of African Parinari.

In order to accumulate as much information as possible to make decisions about the generic concepts of the family I sought morphological evidence from as many fields as possible and the facilities available at Oxford were good for this. I spent much time in the wood anatomy laboratory of Dr. Laurence Chalk, although the technicians were not very keen on this study because the silica content of Chrysobalanaceae wood quickly blunted the knives of their microtomes. I was also able to use the pollen laboratory of Dr. Geoffrey W. Dimbleby to review the pollen of each genus. It was these early studies of wood anatomy and pollen morphology that quickly convinced me that the Chrysobalanaceae was not closely related to the Rosaceae because of significant differences in both the wood structure and pollen morphology, and that I should follow those previous workers who had recognized it as a separate family. I was also able to obtain seeds of several species of Chrysobalanaceae from overseas collaborators and so blastogeny provided another source of taxonomic characters. It was useful to see that disparate species placed in Parinari even had different types of germination. This all led to the accumulation of a large number of 
characters to analyse for making decisions about the genera. Fortnightly visits were made usually together with Frank White to the London herbaria of the Natural History Museum (BM) and the Royal Botanic Gardens, Kew (K).

Table 1 shows the division of the genera of Chrysobalanaceae by four previous systems. This indicates that there were a few differences, but much agreement about the genera. Brown (1818) and Fritsch (1888) treated the group as a family, while Hooker (1865) and Focke (1891) regarded it as a subfamily of Rosaceae. I took as a starting point for my study the twelve genera of Focke (1891) which he divided into two subtribes based on the insertion of the ovary in the receptacle, Chrysobalaninae actinomorphic with the ovary inserted at the base of the receptacle, and Hirtellinae more zygomorphic with the ovary inserted at or near the mouth of the receptacle. To these I added three genera described after Focke (1891): Magnistipula Engler (1905), Geobalanus Small (1913) and Afrolicania Mildbraed (1921) so the starting point for my study was fifteen previously accepted genera.

\section{Rejecting Lecostemon and Stylobasium}

The defining morphological characteristic of the Chrysobalanaceae is the gynobasic style, a relatively rare feature in the angiosperms. All the genera treated in Focke (1891) and Table 1 have this feature. It soon became apparent to me from the wood anatomy and pollen morphology that despite having a gynobasic style, Stylobasium and Lecostemon did not belong with the other genera. Fritsch (1888) had already placed these genera into two separate subfamilies of the Chrysobalanaceae. The inclusion of Lecostemon in Chrysobalanaceae was proposed by Bentham (1853). He decided that four new species he described from South America belonged to the Chrysobalanoideae because of their gynobasic style and he placed them in Lecostemon a genus described by De Candolle (1825) based on a Mociño \& Sessé drawing from Mexico. Huber (1909) realised that the four species of Lecostemon described by Bentham belonged to the then recently described genus Rhabdodendron Gilg and Pilger (1905) at that time placed in the Rutaceae, and so he made the transfer. It is now clear from the discovery of the original type drawing (Fig. 1) that Lecostemon belongs to the genus Sloanea (Elaeocarpaceae), see Prance (1968a). I excluded Rhabdodendron (Lecostemon) from the Chrysobalanaceae mainly based on the anomalous secondary phloem of the wood and the punctate leaves. I placed it in its own family with the suggestion that it belonged near the Phytolaccaceae, another family with secondary phloem. For many years this was disputed and the rutaceous affinity defended by several researchers (for example, by Puff and Weber, 1976), but our later molecular evidence has clearly shown that Rhabdodendron is indeed in the Caryophyllidae together with the Phytolaccaceae (Fay et al., 1997).

Stylobasium was another early exclusion from the Chrysobalanaceae. It was soon apparent to me that this small genus of two species of shrubs from Australia differs from Chrysobalanaceae in all important aspects including floral morphology, leaf anatomy, wood anatomy, pollen grain structure and blastogeny. The details of this study are given in Prance (1965). My suggestion then was that Stylobasium was so different that the family of Stylobasiaceae Agardh (1858) should be recognised and that it belonged in the Sapindales near to Sapindaceae and Anacardiaceae where Desfontaines (1819) suggested it be placed when he described the genus. More recent work has shown that Stylobasium is very close to Suriana and should be placed in the 


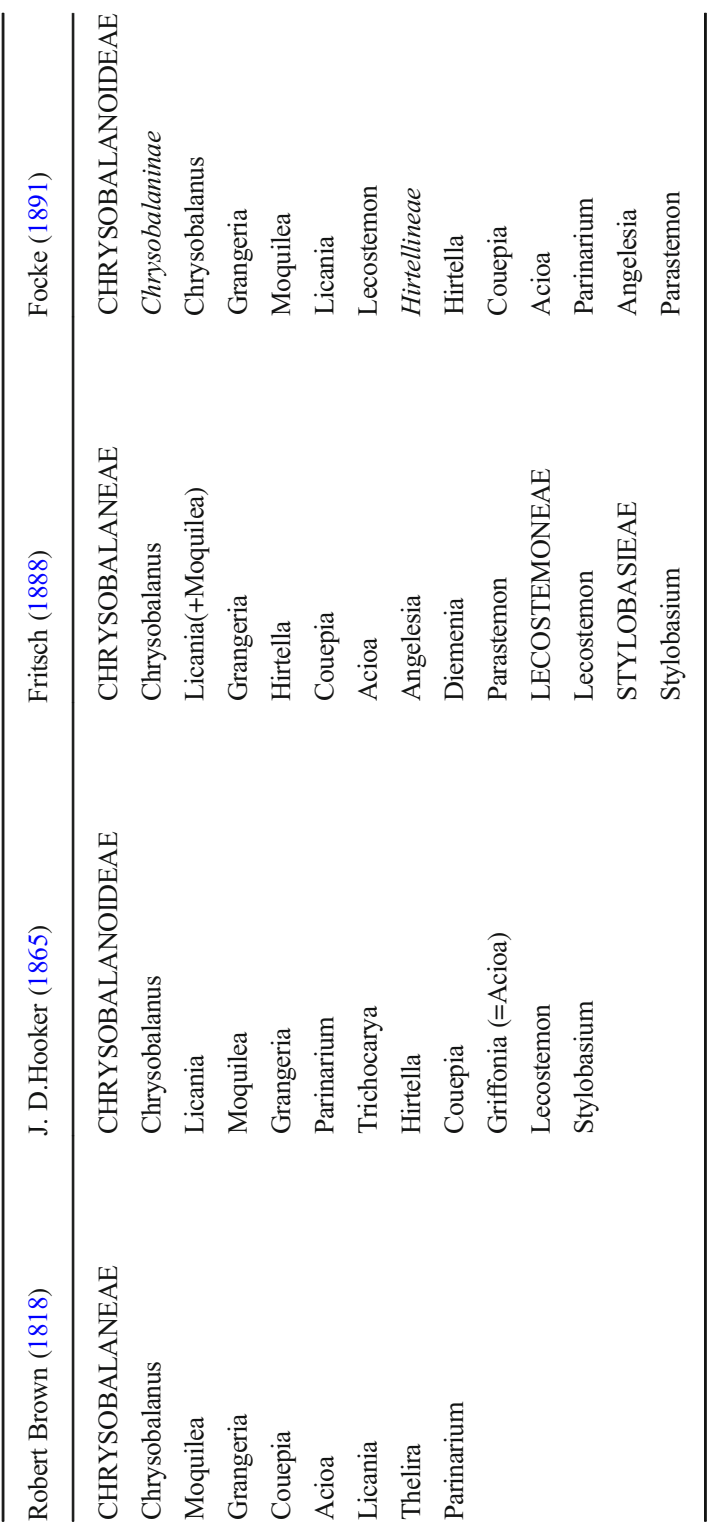

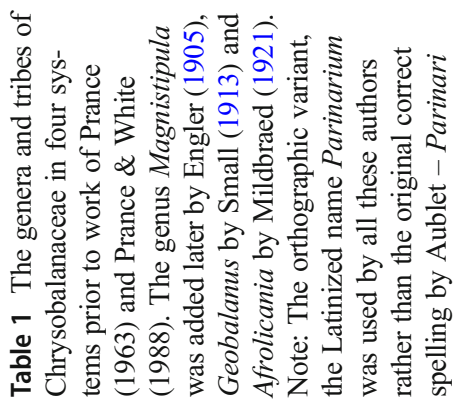




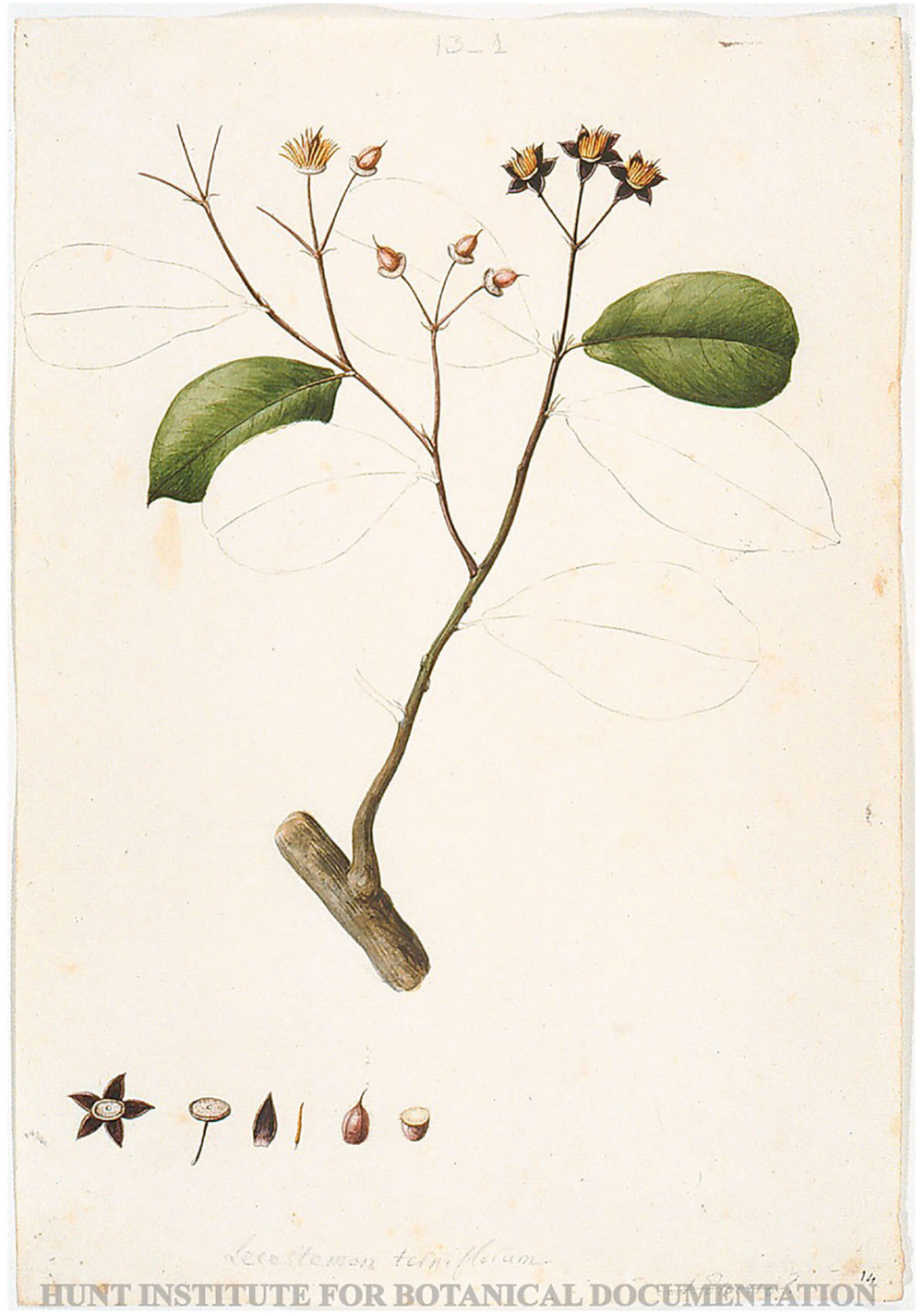

Fig. 1 The holotype of Lecostemon terniflorum a drawing by Mociño \& Sessé (=Sloanea terniflora (Moc. \& Sessé) Standl. erroneously placed in the Chrysobalanaceae. From the Torner Collection of Sessé and Mociño Biological Illustrations, courtesy of the Hunt Institute for Botanical Documentation, Carnegie Mellon University, Pittsburgh, $\mathrm{Pa}$

Surianaceae which has affinities to the Polygalaceae and the Fabaceae (Fernando et al., 1993; Soltis \& Soltis, 2000).

\section{Phenetics and Changes in Generic Boundaries}

Having rejected Stylobasium and Lecostemon (Rhabdodendron) from the Chrysobalanaceae my doctoral work continued to sort out the remaining thirteen 
genera. The initial phase was to gather as much information as possible to distinguish these genera. This included pollen morphology (Fig. 2), wood anatomy (Fig. 3), seed germination and a detailed study of the herbarium specimens at Oxford (FHO \& OXF), Kew (K) and the London Natural History Museum (BM). This study of 254 species of Chrysobalanaceae accumulated a large data set. My work coincided with the emergence of numerical taxonomy (phenetics) and so I decided with encouragement from my supervisor to investigate this emerging field to analyse my data. This was one of the first applications of taximetrics to analyse a sizeable group of higher organisms above the species level. Character state data were gathered for 140 species from which I had sufficient data. This consisted of 21 characters, most of them with multiple character states. The methods and the full results were reported in detail in Prance et al. (1969). During the time at Oxford on my thesis work I used two taximetric methods, Association Analysis (Williams \& Lance, 1958; Williams \& Lambert, 1959, 1960) and Principal Component Analysis (PCA, Jeffers, 1962). The PCA programmes of both Williams and Jeffers proved more useful for taxonomic data than the Association Analysis, a method mainly used for ecological data (Figs. 4, 5). The PCA analysis clearly showed that Parinari was an artificial agglomeration of species and it eventually led me to divide the genus into eight separate genera (Table 2; Prance \& White 1988). In 1963 after completing my doctorate (Prance, 1963) I moved to The New York Botanical Garden where I was fortunate to meet fellow staff member David J. Rogers who was also an early pioneer of taximetrics. He and I were soon collaborating, and it led to analysing my Chrysobalanaceae data by two methods of cluster analysis those of Rogers and associates (Rogers et al., 1967; Wirth et al., 1966) and of J. Rubin (Rubin,
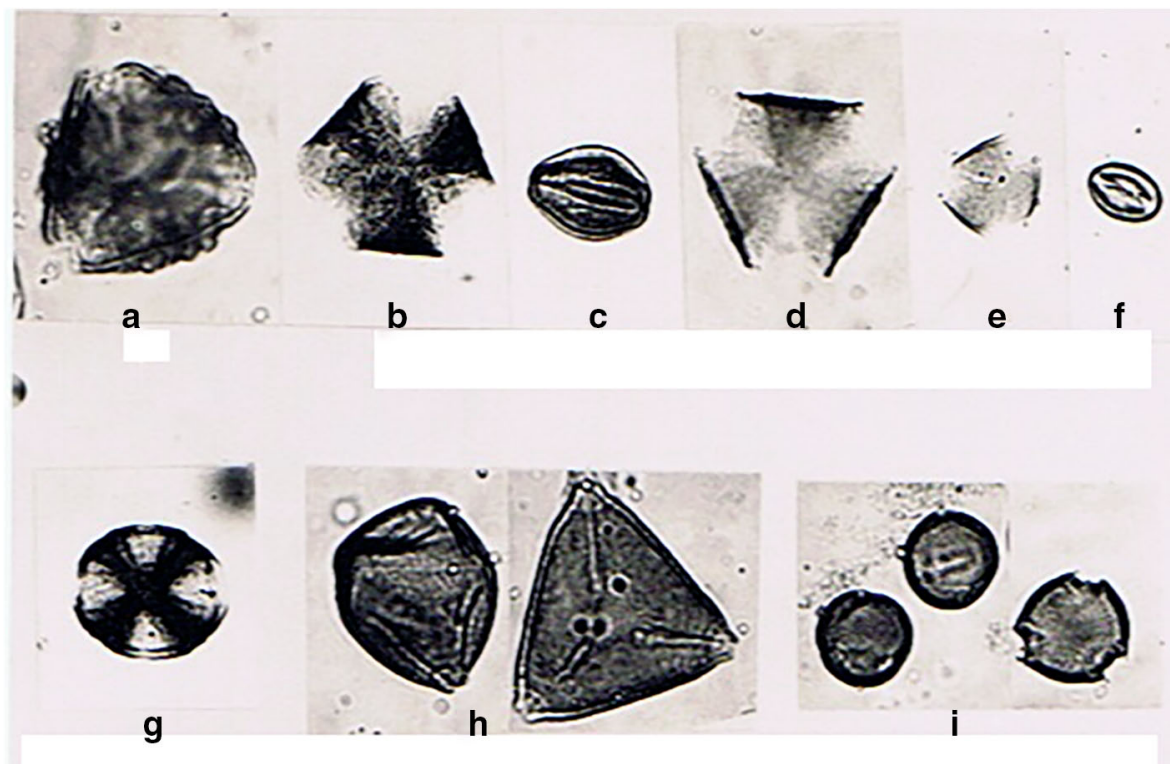

Fig. 2 The pollen of Chrysobalanaceae and excluded genera: a-g Chrysobalanaceae: a. Kostermanthus heteropetalus (Scotech. ex King) Prance; b,c,g. Hirtella glandulosa Spreng; d. Chrysobalanus icaco L; e,f. Grangeria borbonica Lam.; h. Stylobasium spathulatum Desf.; i. Rhabdodendron amazonicum (Spruce ex Benth.) Huber 


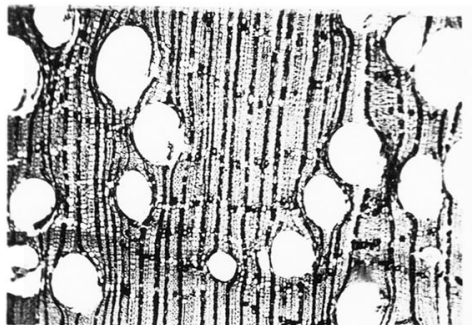

a

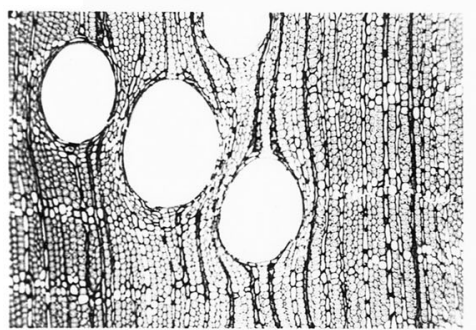

b

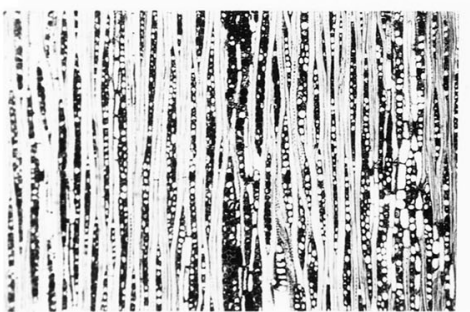

C
$10 \mathrm{~cm}$ d
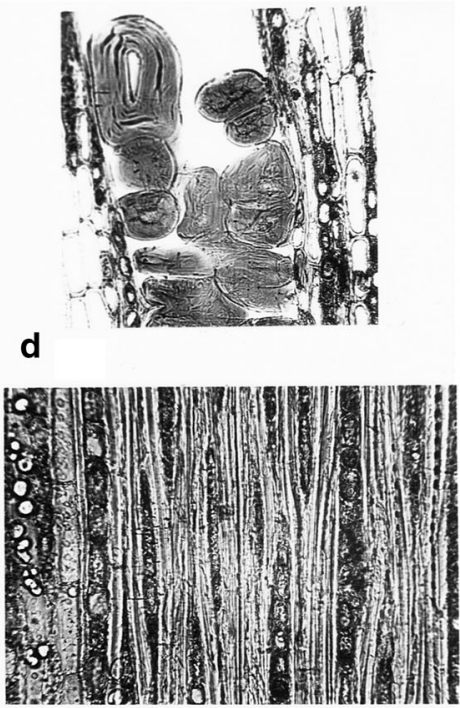

e

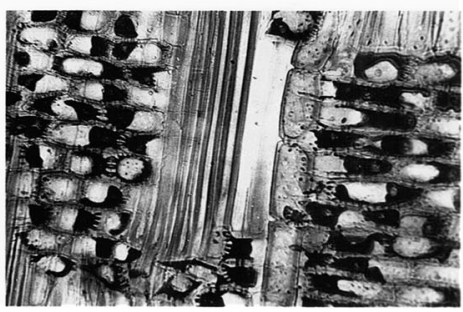

$\mathbf{f}$

Fig. 3 The wood of Chrysobalanaceae: a Hymenopus heteromorphus (Benth.) Sothers \& Prance, X.S. b Parinari excelsa Sabine, X.S; c Maranthes corymbosa Blume, T.S. d Angelesia splendens Korth. T.S full of tyloses. e Couepia guianensis Aubl. subsp. glandulosa (Miq.) Prance, T.S. f Chrysobalanus icaco L., T. S

1967, Fig. 6). The results from all these methods were compared in Prance et al. (1969), and they all told the same story that to recognise the genera using consistent criteria throughout the family Parinari needed to be split up.

The first of these changes to Parinari sens. lat. was published in Prance (1966b) in a paper about the Angolan species of Chrysobalanaceae, where the old name Maranthes of Blume (1825) was revived for Parinari subgenus Sarcostegia Benth. and Parinari tessmannii Engl. was transferred to Magnistipula. Exellodendron, the only Neotropical split from Parinari, was established in Prance (1972a) for four species that were quite distinct from the rest, particularly by their small smooth fruit and the absence of stomatal cavities on the underside of the leaves so typical of Parinari sens. str. This new genus was named to honour Arthur Exell from the London Natural History Museum (BM) who acted as my thesis supervisor for six months while Frank White was on an extended field trip to Nigeria. The remainder of the segregates from Parinari were treated in several different publications. Two small monospecific West African segregates from Parinari, Bafodeya and Neocarya were described and published by me in White (1976). Kostermanthus was described in Prance (1979a) to accommodate 


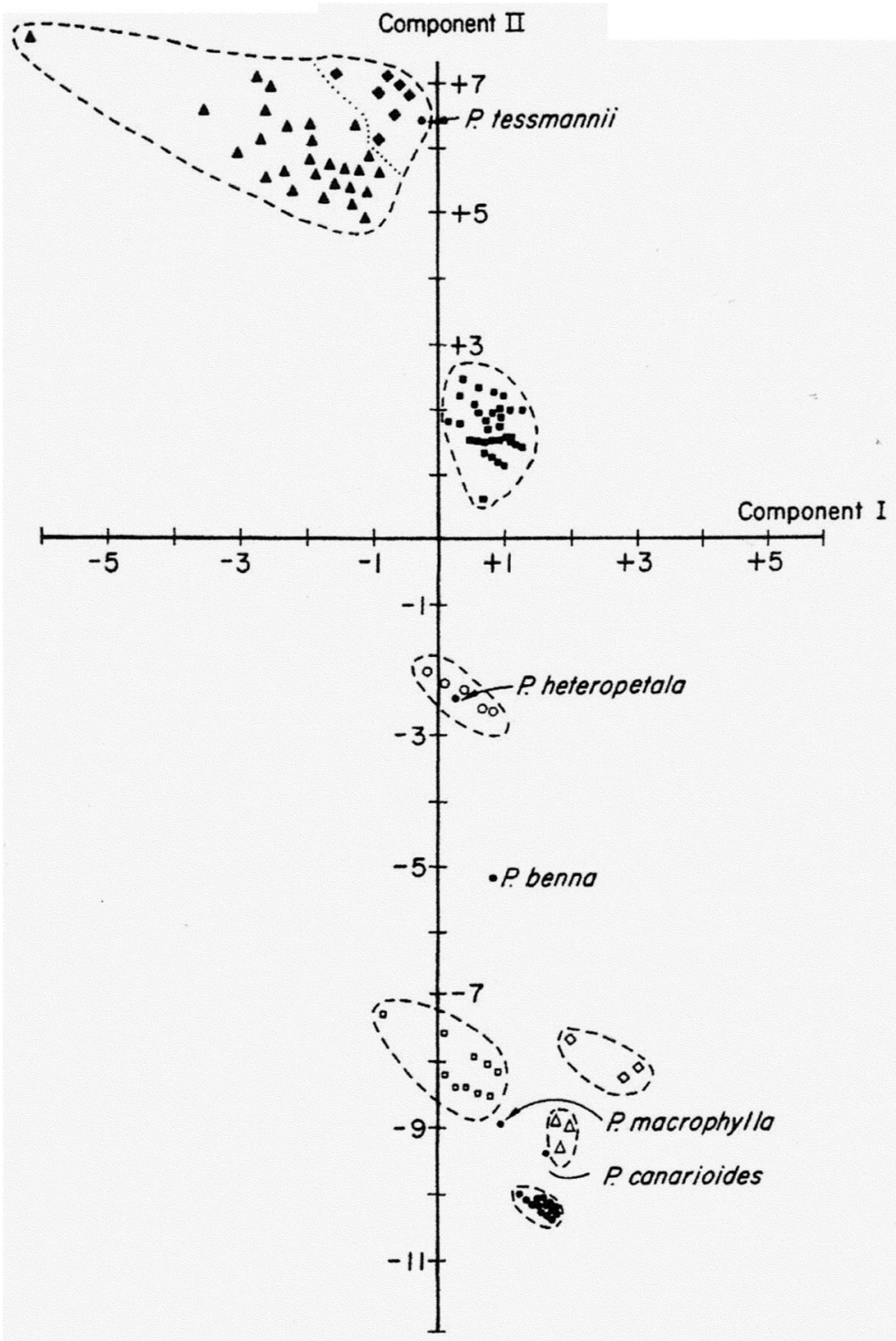

Fig. 4 Projection of the first two components from the Williams Principal Component Analysis of Chrysobalanaceae, from Prance et al., 1969, showing former species of Parinari scattered in many places: filled circle - Parinari sens str.; open circles Atuna, open triangles Exellodendron, open squares Maranthes. Destination of named species: P. tessmannii=Magnistipula tessmannii (Engl.) Prance; $P$. heteropetala $=$ Kostermanthus heteropetalus (Scortech. ex King) Prance; $P$. benna = Bafodeya benna (Scott-Elliott) Prance; P. macrophylla $=$ Neocarya macrophylla (Sabine) Prance; $P$. canarioides remains in Parinari

Parinari myriandra Scortechini ex King, a species that did not even have the single uniting character of Parinari sens. Lat., a bilocular ovary. The ovary of Kostermanthus is unilocular and in addition it has stamens fused into a ligule which is not a feature of Parinari but occurs in the Neotropical genus Acioa and the African genus Dactyladenia. At some time in the past all three genera with a fused staminal ligule 


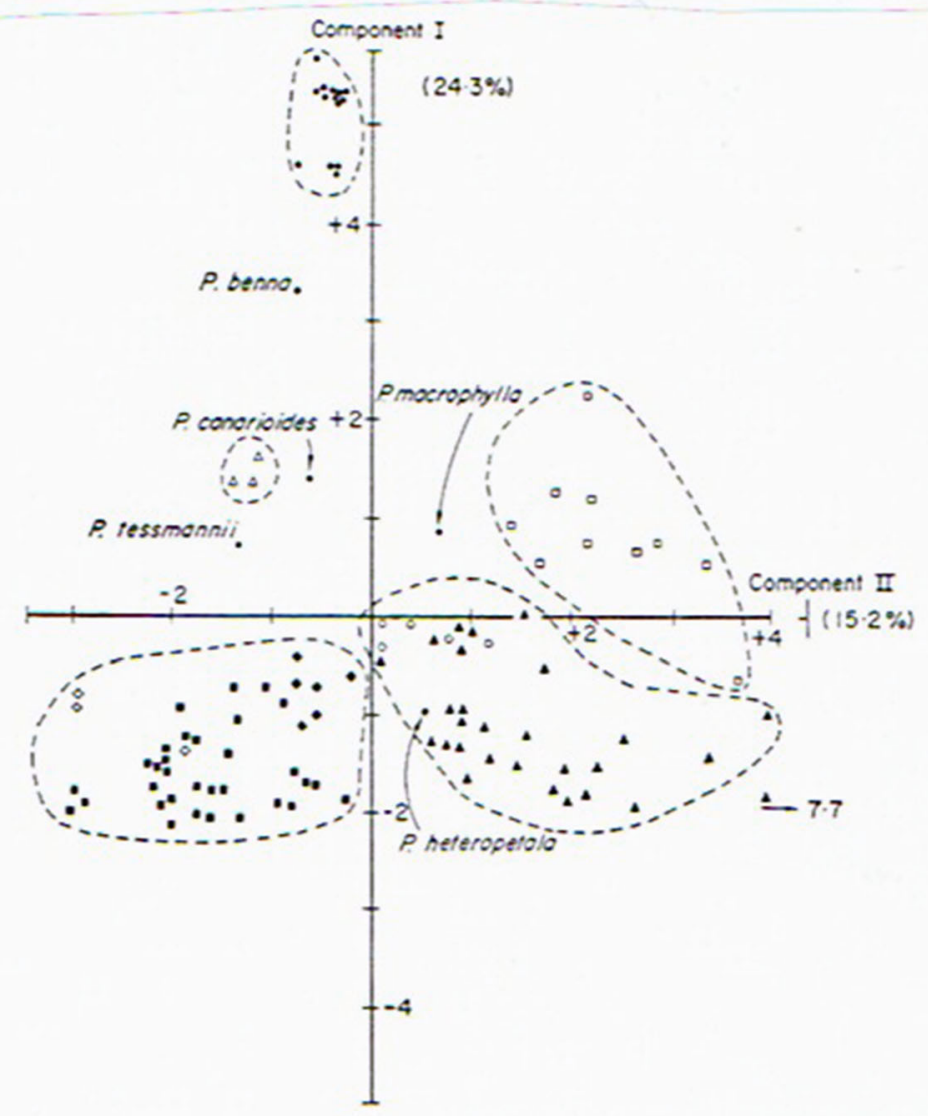

Fig. 5 Projection of the first two components from the Jeffers Principal Component Analysis of Chrysobalanaceae, (from Prance et al., 1969). Key to symbols and names as in Fig. 3

were merged together into Acioa. Kostermans (1965) had already transferred P. myriandra to Acioa and described two more species of the genus from Malaysia and Indonesia. This is not supported by our later work which showed that the fusion of stamens into a ligule has evolved separately on all three continents, consequently the three genera with fused stamens are now regarded as separate and valid. The new genus

Table 2 The genera and tribes as defined in Prance \& White (1988). The genera that were formerly included in Parinari are in bold face

\begin{tabular}{llll}
\hline Chrysobalaneae & Parinarieae & Couepieae & Hirtelleae \\
\hline Chrysobalanus & Parinari & Couepia & Hirtella \\
Licania (+Moquilea & Bafodeya & Maranthes & Dactyladenia \\
$\&$ Afrolicania) & Neocarya & Acioa & Kostermanthus \\
Parastemon & Exellodendron & & Magnistipula \\
Grangeria & Hunga & & Atuna \\
\hline
\end{tabular}




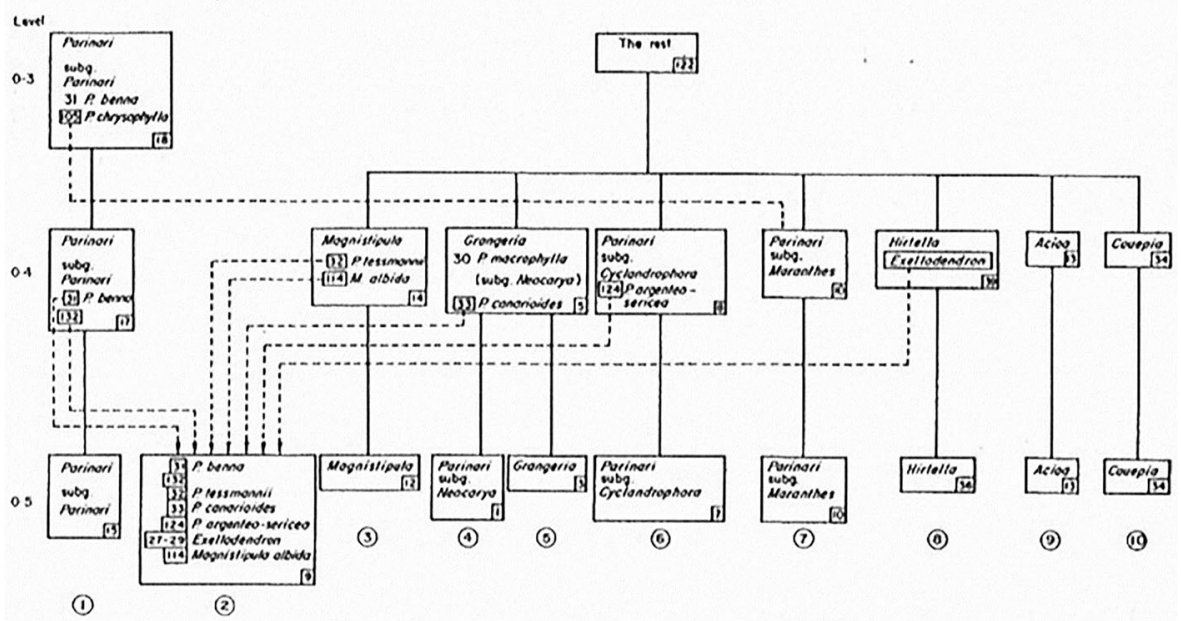

Fig. 6 An example of one of the cluster analyses of Chrysobalanaceae: This one from the Rubin method. The boxes represent the cluster and inside the contents are given. The dashed lines show which species cross over to different clusters between the similarity levels. Box contents, using current names: 1. Parinari sens. str.; 2. Bafodeya, Magnistipula tessmannii = subgenus Pellegriniella, Exellodendron and Parinari subgenus anareolata Kosterm.; 3. Magnistipula sens. str.; 4. Neocarya; 5 Grangeria; 6. Atuna; 7 Maranthes; 8. Hirtella; 9. Acioa; 10 Couepia. The long-established genera come out at the same level as many parts of the former Parinari. (from Prance et al., 1969)

Hunga was described in Prance (1979a) for a distinctive group of eight species from New Caledonia and New Guinea some of which were formerly in Parinari and others in Licania, indicating the confusion of generic boundaries prior to this work. Also, in tropical Asia the old generic names Maranthes Blume and Cyclandrophora Hasskl., long synonymised into Parinari, were revived by me as separate genera (Prance, 1966b, 1968b; Prance et al., 1969). Soon afterwards Kostermans (1969) found that Atuna Raf. was an even older name for Cyclandrophora which is a widespread group in Malesia and Oceania. All these changes to the genera of Chrysobalanaceae are summarized in Table 3 and were published in full detail in Prance et al. (1988).

\section{Fieldwork}

During the studies for my doctoral thesis at Oxford I borrowed a considerable amount of herbarium material from other herbaria. One of those loans was from the New York

Table 3 The re-organization of Couepia in Sothers et al. (2014) divided to obtain monophyly

Couepia sens str.

Gaullettia new genus for 9 species formerly in Couepia

Couepia recurva Spruce ex Prance transferred to Hirtella

Couepia platycalyx Cuatr. transferred to Licania

Couepia longipendula Pilg. and C. dolichopoda Prance transferred to Acioa. 
Botanical Garden, which holds several of the type specimens that I needed to examine. In the absence of Dr. Bassett Maguire, the curator of the NY herbarium, Howard Irwin was in charge and he considered my request reasonable and so provided me with a large number of important specimens on loan for study. On the return of Maguire from a field trip to the Serra da Neblina in Brazil Irwin was reprimanded for sending the Chrysobalanaceae specimens because Maguire had accumulated a large collection with the intention of working on the taxonomy himself. However, this all worked out for the good for me as a year later Frank White received a letter from Maguire asking two things, firstly would White recommend me as a possible candidate for a postdoc to work up his accumulated Chrysobalanaceae specimens and secondly did he think I would be interested. Maguire had many commitments and realised that he would never get to study the large amount of Chrysobalanaceae specimens in his possession. I enthusiastically accepted this offer because it was a logical follow up to my thesis work instead of the postdoc I had already been offered on East African ecology in Kenya. When negotiations about the arrangements for my new job began, Maguire explained that he did not have any funds to pay for my travel to New York. He said that instead he had funds in the budget of his expedition grant and that he could pay for my travel from that grant if I joined an expedition to the Wilhelmina Gebergte mountains in Suriname. I accepted enthusiastically this even better offer to travel to New York via Suriname and in August 1963 I joined the second half of the six-month expedition led by Howard Irwin, the first half having been led by Maguire (Fig. 7). The details of this expedition are given in my book (Prance 2014c) and so I will refer only to information relevant to the Chrysobalanaceae. Two things were important for me: I was in the field with a really good tropical botanist who was an excellent teacher, and I was in a center of diversity of the Chrysobalanaceae. Almost as soon as I arrived in Suriname I was in a savanna near the airport with Dutch botanist Dr. J. P. Schulz examining Hirtella paniculata Sw. (Fig. 7B) and Licania incana Aubl. one of the species of Chrysobalanaceae described by Aublet in 1775. A week later, after various technical delays, I joined Irwin and his team at the base camp of the Wilhelmina expedition. Howard pointed out to me that the tall tree beside one of the shelters was a species of Chrysobalanaceae. We soon had a climber collecting specimens for me of Licania majuscula Sagot. Thus, began my field study of the Chrysobalanaceae and of plants in many other families and this has continued to the present day. My one-year postdoc at The New York Botanical Garden turned into 25 years as a staff member with the opportunity to carry out extensive fieldwork in the South American tropics. The time in Suriname gave me the opportunity to study and collect a number of different species of Chrysobalanaceae. I was delighted that Parinari campestris Aubl. was abundant along the Lucie River by our base camp and that Chrysobalanus icaco L. and Hirtella racemosa Lam. were abundant in the savanna surrounding the Kaiser airstrip from which we flew in and out of the interior. Collections of Couepia obovata Ducke and C. caryophylloides R. Ben. provided me with my first collections of that genus. I was fascinated by Hirtella physophora Mart. \& Zucc. (Fig. 8B) because it had swollen domatia at the base of the leaf lamina that were inhabited by small ants. The 39 collections of 18 species in five genera from Suriname was an excellent beginning for my field studies of the Chrysobalanaceae. The other benefit of joining that expedition was the mentoring I received from Howard Irwin, who knew the plant families so well and instructed me both on plant family identification and on collecting 

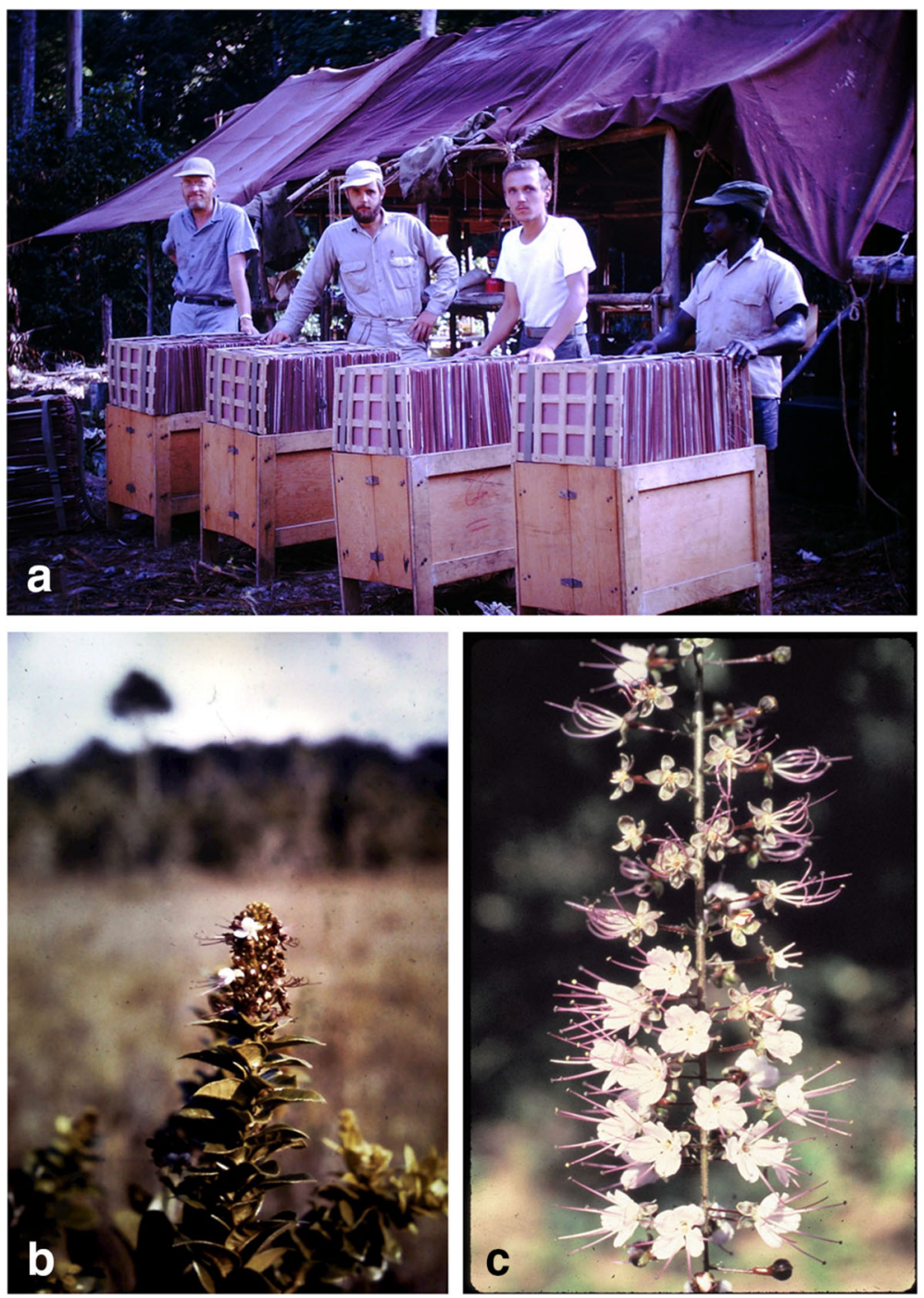

Fig. 7 The Suriname expedition. a The team members left to right: Howard Irwin, Noel Holmgren, Thomas Soderstrom, Frederik. b My first photo of Chrysobalanaceae, Hirtella paniculata Sw. c Hirtella racemosa Lam. Also in Suriname

methods. This set me up well for the future because in August 1964 I was on my own expedition in Brazil with two experienced mateiros (field botanists), Nilo da Silva and Bento Pena. More details of my 39 plant collecting expeditions while I was at The New York Botanical Garden are given in Prance (2014c) and here I just want to refer to the importance and relevance of fieldwork for monographic studies.

During my doctoral studies I had many discussions with Frank White about the functional syndromes that led to the morphological differences I was using for my taxonomic decisions. Functional syndromes were a passion of Frank's and so in his memory several of his former students and associates published a Festschrift for him on the topic, The Biological Monograph (Hopkins et al., 1998). Frank wrote in Prance \& 

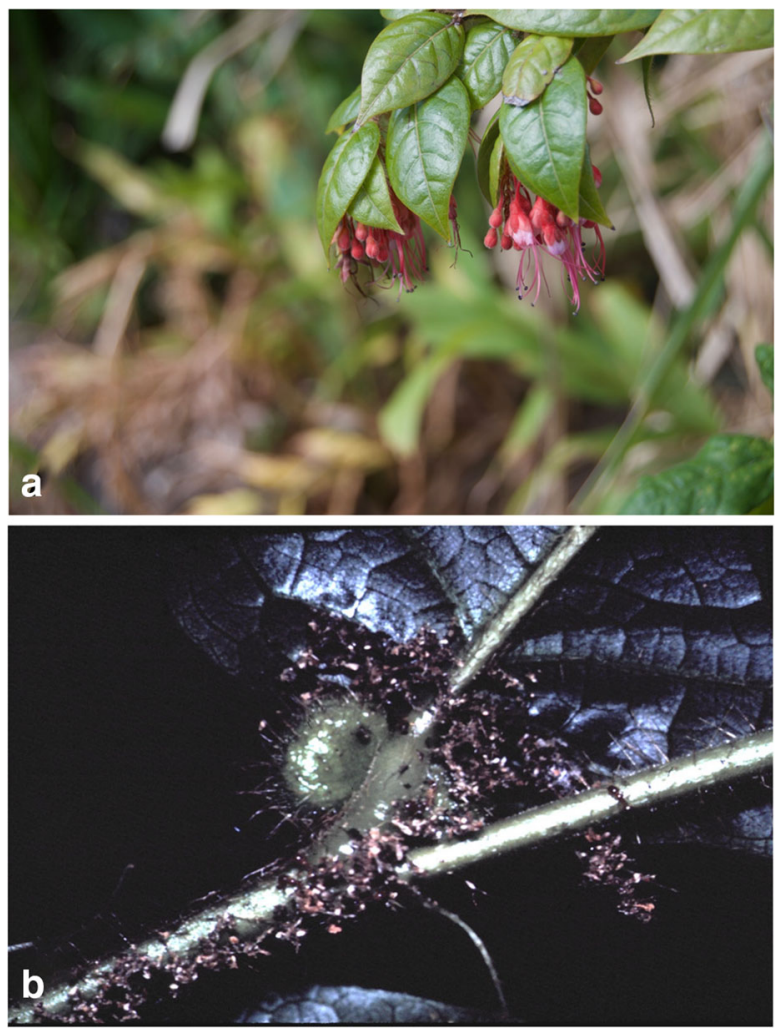

Fig. 8 Two examples of Hirtella. a Hirtella rugosa Thuill. ex Pers. from Puerto Rico with redder and more closed flowers than other species of the genus and is pollinated by hummingbirds b Hirtella physophora Mart. \& Zucc. has swellings at the leaf bases occupied by ants, a mutualism that helps to defend the leaves from predators

White (1988): "Without ecological understanding taxonomy is lifeless and dull, and taxonomically important information goes undetected." I remember discussing with Frank the reasons for the differences in flower structure between the genera Couepia and Hirtella, and before I had seen any of them in the field we decided that Couepia with its white flowers and a mass of brush-like stamens must be a moth pollinated genus and that Hirtella often with red flowers and fewer stiff, erect stamens was probably by pollinated butterflies. This has proved to largely true from my field observations except for the bat-pollinated flagelliflorous Couepia longipendula Pilg. And $C$. dolichopoda Prance (both later transferred to the genus Acioa). The understanding of the biological role of the morphological characters used to define species and genera is essential for all taxonomic work. These characteristics are largely derived from co-evolution with pollinators, agents of dispersal, herbivores and seed predators and in adaptation to different ecological niches.

Fieldwork allows one to understand the ecology of the taxa under study. The Chrysobalanaceae, predominantly a lowland group, has adapted to many different habitats, and knowledge about this is most useful addition information for defining species boundaries. An example is the five species of the South American genus Exellodendron, one of the segregate genera from Parinari. Exellodendron barbatum 
(Ducke) Prance is a species of terra firme forest and riversides, E. coriaceum (Benth.) Prance is a species of savannas and savanna margins, E. cordatum (Hook. f.) Prance is found in the caatinga forest of northeastern Brazil, E. gardneri (Hook. f.) Prance is found in the cerrado of central Brazil and E. gracile (Kuhlmann) Prance is a rare species of the Mata Atlántica of the state of Espírito Santo. In Amazonia there are many pairs of closely related species where one grows in the upland terra firme forest and the other in the periodically flooded várzea forest. Two examples of this are Hymenopus oblongifolius (Standl.) Sothers \& Prance on the terra firme and the closely related H. macrophylla (Benth.) Sothers \& Prance on the periodically flooded várzea forest or Parinari campestris Aubl. in the riverine gallery forest and P. rodolphii Huber in the terra firme forest. Parinari is generally a genus of very large trees on all three continents where it occurs, but it is interesting that the genus has evolved a geoxylic suffrutex species on all three continents as an adaptation to poorer soils and open fireprone habitats: Parinari obtusifolia Benth. (Fig. 9A) in the cerrado vegetation of Brazil, $P$. capensis Harv. in the Kalahari sands of Africa (Fig. 9B) and P. nonda Benth. in the savannas of northern Australia; I have been able to study all three species in the field.

In my monograph of Neotropical Chrysobalanaceae, Prance (1972a), I lumped together a polymorphic assemblage of specimens under the aptly named Licania heteromorpha Benth. (now Hymenopus heteromorphus (Benth.) Sothers \& Prance). After extensive fieldwork for the Flora of the Ducke Forest Reserve some segregate species began to make sense and I described Licania adolphoduckei Prance, L. laevigata Prance, L. occultans Prance and L. sothersii Prance (now after the molecular work described below all are species of Hymenopus). Hymenopus heteromorphus is still in need of further work and a phylogenomic study would help to work on the true taxonomy of this ochlospecies. Incidentally this shows how important intensive fieldwork is when writing Floras. In a small ten-thousand hectare reserve where I had been many times during the previous twenty years the field studies for the Flora yielded two new species of Chrysobalanaceae, Licania adolphoduckei and L. sothersii.

I had often wondered why the flowers of Hirtella rugosa Thuill. ex Pers. (Fig. 8A) from the mountains of Puerto Rico were so different from the rest of the genus until I made some field observations and saw hummingbirds visiting the flowers of this species of an otherwise predominantly butterfly-pollinated genus. Two small changes evolved to allow this adaptation to a more appropriate pollinator in this windy montane habitat: the calyx is coloured scarlet rather than green and it does not spread open as in other species of Hirtella. Instead, it forms a scarlet tube that keeps the 3 stamens erect and ready to brush into the chest of a visiting bird. There is no doubt that fieldwork has helped to improve my taxonomy in Chrysobalanaceae and in other families that I have studied.

\section{Monographs}

The first major product of my research and early fieldwork in Suriname and Brazil was a monograph of the Chrysobalanaceae for Flora Neotropica (Prance, 1972a). This treated the 328 American species including 84 new species and the reduction of many previous names into synonymy. The fact that there were so many new species indicated 

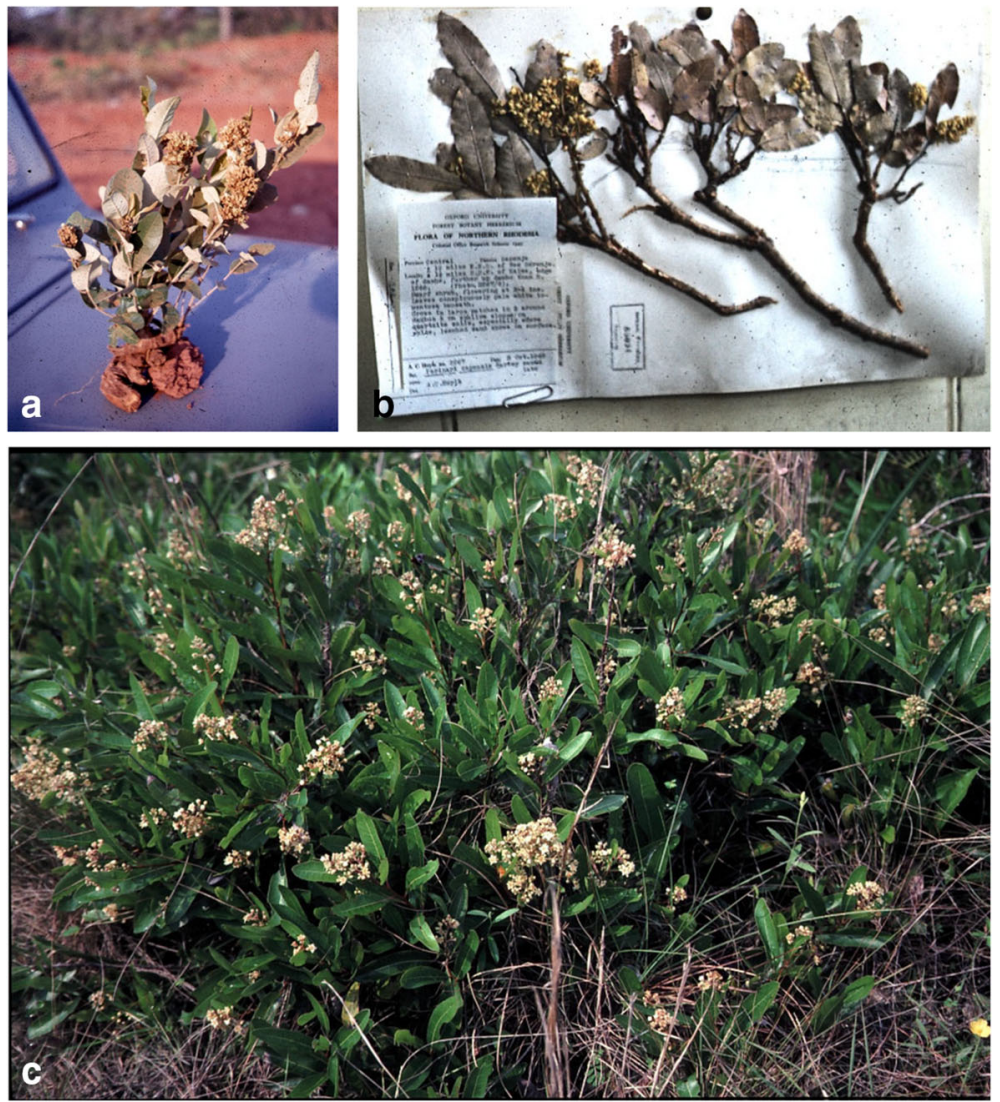

Fig. 9 A few species of Chrysobalanaceae are geoxylic suffruteces and examples. a Parinari obtusifolia Hook. f. from the cerrado region of Brazil. b Parinari capensis from the Kalahari sands of Africa. c Geobalanus oblongifolium (Michx) Small from the everglades of Florida

the need for that study. By 1989 so much more new information had been gathered from the fieldwork by many people that a supplement to the original monograph was necessary (Prance, 1989a). This included the 63 new species that had been described in the fifteen years since the 1972 monograph. This was followed by a treatment of the 35 Asian and Malesian species for Flora Malesiana (Prance, 1989b). Next was a treatment of all 531 species of the family then known in Species plantarum, Flora of the World (Prance \& Sothers, 2003a, 2003b). This included the species from Africa and Oceania that had not been treated in the earlier works. As new molecular techniques emerged, this well-established baseline taxonomy of a large tropical family has greatly facilitated progress in Chrysobalanaceae research as discussed below. I have previously stressed the importance of morphology-based monographs as a basis for much further research in biogeography, ecology and conservation (Prance 1985b; Prance 2011) and I continue to stress this here because many large and important tropical plant groups are still lacking definitive monographs. For this reason I have continued monographic work beyond the Chrysobalanaceae: in Lecythidaceae (Prance \& Mori, 1979; Mori \& Prance, 1990), Proteaceae (Prance et al., 2008b) and Rhizophoraceae (Prance, 2018). It is the morphological species that is the basic unit of conservation and plant use as well as 
being the concept of organisms most understood by the general public at large. Mayo and Allkin (2008) referred to this as the 'reification' of the species, that is the transformation of an abstract idea into a material object. The data centralized in monographs provide much of the information needed for conservation. They have been extensively used to locate hotspots and centres of diversity and to compile the data for IUCN Red Lists. Another example of the use of monographs in research is the study of the floristics of white-sand forests of García-Villacorta et al. (2016) who used the Chrysobalanaceae monographs and Pennington's (1990) monograph of the Sapotaceae as a basis for this research on the floristic links between different areas of forest on white sand in the Guianas and Amazonia.

\section{Economic Botany}

An important aspect of fieldwork and compiling data for monographs is that both help one to learn about the various uses for the plants that one is studying. This has certainly been true in the Chrysobalanaceae (Prance 2005) and has taken me into some interesting ethnobotanical studies (Fig. 10). The species that gives its name to the family, Chrysobalanus icaco L. or the cocoa plum is a popular fruit around the coastal areas of the Caribbean and eastern South America. Hicacos, as the fruit is called locally, are bottled in sugar and sold in Colombia and Venezuela and the fruit eaten as far South as Rio de Janeiro. Many species of Chrysobalanaceae produce edible fruits that are popular in local markets because of the fleshy mesocarp of the drupaceous fruits, for example, Couepia subcordata Benth. ex Hook. f. (mari-mari) and C. bracteosa Benth. (pajurá, Fig. 10A) in Amazonia and C. rufa Ducke (oiti coro) in the markets of Pernambuco. The fruits of Parinari excelsa Sabine and P. curatellifolia Harv. ex Sond. are much eaten in Africa. Charred kernels of a species of Parinari have been found at archaeological sites on the Nyika Plateau of Malawi and found as fossils (Tiffney et al. (1994). The fruit of Moquilea platypus Hemsl. has been used since prehispanic times in Mexico (Ochoterena-Booth \& Olvera, 1992) and is still a popular fruit today. Moquilea tomentosa Benth., from northeastern Brazil, is a popular fruit, but is most used as a shade tree for streets in many towns throughout Brazil. The cotyledons of many Chrysobalanaceae produce useful oils. Atuna excelsa (Jack) Kosterm. subsp. racemosa (Rafin) Prance (local name ififi), a widely distributed species in Malesia and Oceana, has an oil that is used as a medical massage in Samoa and Fiji (Fig. 10D, E, F, G; Prance et al., 2008, Prance, 2008c). It has been shown that this oil does indeed have anti-inflammatory properties (Noreen et al., 1999; Prance 2005). Other species have oils that are used for lighting or cooking. Mexican natives used to string up cotyledons of Licania arborea Seem. (now Microdesmia arborea (Seem.) Sothers \& Prance) to burn progressively along the line as lamps and the same use for Chrysobalanus icaco seeds was recorded by Morton (1981). Microdesmia arborea and the closely related M. rigida (Benth.) Sothers \& Prance from northeastern Brazil yield a fast-drying oil similar to that of Aleurites, the source of tung oil which has been much used in paints. Various species of Acioa have furnished a popular cooking and lighting oil in Central and Western Amazonia, Acioa longipendula (Pilg.) Sothers \& Prance used to be cultivated and used for its edible oil around Manaus, and A. dolichopoda (Prance) Sothers \& Prance in Colombia and Peru and A. edulis Prance in the Purus River region 

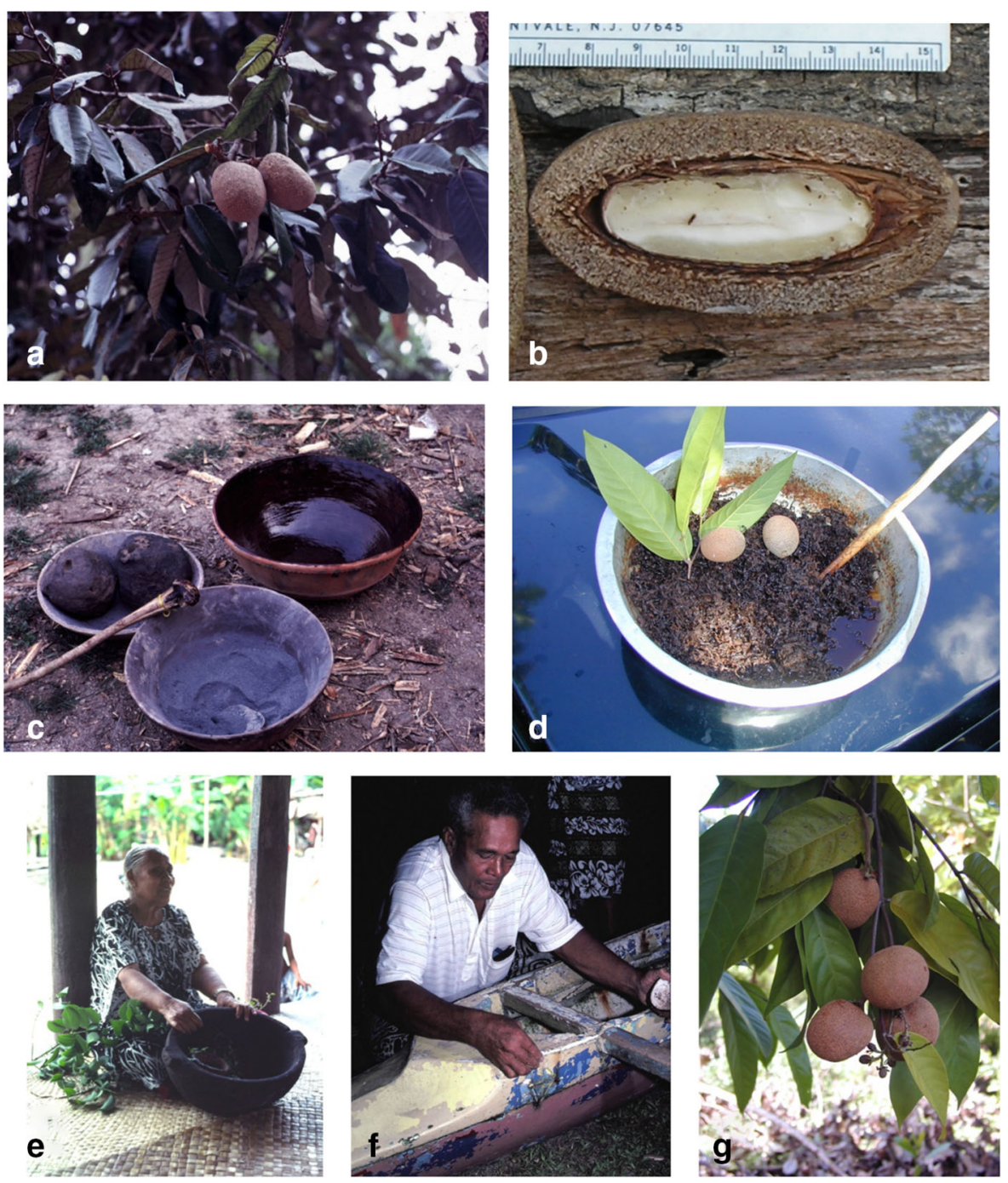

Fig. 10 Uses of the Chrysobalanaceae. a edible fruit of the pajurá, Couepia bracteosa Benth. b the oilproducing seed of castanha de cutia, Acioa edulis Prance. $\mathbf{c}$ the bark ash of Licania species used in indigenous ceramics throughout Amazonia. $\mathbf{d}$ the fruit and pulp of Atuna excelsa (Jack) Kostermans used to treat bruising injuries. e a samoan healer preparing Atuna oil. f a samoan man caulking his boat with the pulp of Atuna seeds after the oil is extracted. $\mathbf{g}$ the fruits of Atuna excelsa.

of Brazil are still in use today. One of the most unusual uses of the family is by many indigenous peoples in the Amazon who use the bark ash of various species of Licania and Couepia to harden their pottery vessels (Fig. 10C). This is due to the silica content of the bark that enables them to be used as cooking vessels that can be placed on fires. Knowledge of this use has spread from Peru at the foot of the Andes through to Marajo island in the Amazon Delta region (see Beck \& Prance, 1992; Prance 2005). There are also many reports of the use of species of Chrysobalanaceae in folk medicine for 
example of Chrysobalanus icaco (Vargas et al., 2010; Paracampo et al., 2017) the leaves of which have been used for a tea to treat leucorrhea, haemorrhages and chronic diarrhea. Carnevale Neto et al. (2013) reviewed the chemistry and the medicinal uses from many worldwide sources for several species of Licania sens. lat. and Parinari, and for Chrysobalanus icaco.

\section{Phytogeography and Conservation}

The accumulation of biogeographic information together with habitat data from fieldwork gives the opportunity to analyse these data for conservation purposes. Monographs contain distribution maps of all the species, and they are becoming increasingly easy to manipulate with computerised mapping and are useful for biogeographic and conservation studies. Soon after producing my first monograph data available I began to use them to determine areas of endemism and likely Pleistocene forest refugia in Amazonia (Prance 1974a) and to delimit the phytogeographical regions on Amazonia (Prance 1977). In Workshop 90 in Manaus Brazil in 1990 on Biological priorities for conservation in Amazonia (Prance 1990a), the data from my monographs of Chrysobalanaceae (Prance, 1972a), Lecythidaceae (Prance \& Mori, 1979; Mori \& Prance, 1990), Dichapetalaceae (Prance, 1972b) and Caryocaraceae (Prance 1973a) was used together with data from other sources to determine priority areas for conservation. Later the data from these monographs was analysed by a more quantitative method using the Worldmap programme of Paul Williams (Williams, 1993; Williams et al., 1996a, 1996b). This enabled an analysis of gaps in the collecting sample as well as centers of diversity. Worldmap automates several simple heuristic techniques for searching for sets of complementary areas to represent species. The algorithm comprises four stages. The first begins by selecting all of the areas with species that are recorded from only one grid cell (i.e. the most narrowly endemic or regionally unique species), because these areas are vitally important for conservation and listing of the species. The second stage continues by selecting a sequence of grid cells to maximize the complementary range-size rarity score at each step, until all species are accounted for at least once. Selecting preferentially for grid cells with the more narrowly distributed species is one way to find a small set of areas that are likely to be important for conservation. The third stage checks back through the selected grid cells for any that lack unique species in order to eliminate redundant grid-cell choices within the selected set. This yields a 'near-minimum-area' set, although marginally smaller, truly minimum-area sets may exist. An optional fourth stage in the heuristic procedure is used to re-order the grid cells of the chosen set into some priority ranking for conservation action. This review concentrates on the developments in monographing the Chrysobalanaceae but I wrote a lot more about this important use of phytogeographic data for conservation planning in Prance (1994a).

\section{The Molecular Revolution and Phylogeny}

The work described above was based on traditional methodologies of phenetics and phyletics based mainly on morphology. As DNA evidence has emerged, in some cases 
this has turned out to be an accurate predictor of relationships and in others less so. Up to the mid-twentieth century Chrysobalanaceae was considered either as a subfamily of the Rosaceae or near to the Rosaceae and Leguminosae in the Rosales. It was also in the Rosales of Cronquist (1988) and of Takhtajan (1969) and in a separate order Chrysobalanales in Takhtajan's Superorder Rosanae in Takhtajan (1996). R. Dahlgren (1980) also placed the family in his order Rosales, but in the final revision of this system it was placed in the order Theales far from the Rosales (G. Dahlgren, 1989), agreeing with the opinion of Thorne (1992). An interesting divergence from the traditional placement of the Chrysobalanaceae in the Rosales was that of Hallier (1923) who suggested a phylogenetic relationship to the Linaceae. He proposed a merger of Chrysobalanaceae, Dichapetalaceae and Trigoniaceae into a single family derived from the Linaceae and Polygalaceae. There is now a consensus from molecular studies that the Chrysobalanaceae belongs to Eurosid I clade in the order Malpighiales (Chase et al., 1993; Davis \& Chase, 2004; Soltis \& Soltis, 2000; APG, 1998; APG IV, 2016). Furthermore, it is close to the Dichapetalaceae, Trigoniaceae and Euphroniaceae supporting the hypothesis of Hallier (1923), and these are the outgroups that we have used for our own molecular work on the family. It is interesting that while working on Chrysobalanaceae I received many specimens for identification of Dichapetalaceae and of Euphronia mistakenly thought to be Chrysobalanaceae. This led me to prepare a monograph of the Neotropical Dichapetalaceae (Prance, 1972b), and to suggest to my student Eduardo Lleras that he work on the Trigoniaceae (including Euphronia at that time) for his doctoral thesis (Lleras, 1978). That was before I was aware of the relationship between Chrysobalanaceae and these families. Various sister-group relationships have been proposed as subclades within the Malpighiales for the Chrysobalanaceae: Trigoniaceae (Chase, 1993) Dichapetalaceae (Soltis \& Soltis, 2000) Balanopaceae (Soltis et al., 2005) and Euphronia (Litt \& Chase, 1999).

More detailed molecular studies within the Chrysobalanaceae began with the doctoral work of Deepthi Yakandawala (née Dissanayake) at Reading University supervised by Cynthia Morton and me (Dissanayake, 1999; Yakandawala et al., 2001, 2010). The aim of this study was to look at the monophyly, or lack thereof, of the genera of Chrysobalanaceae using morphology, rbcL and ITS sequences. Yakandawala was able to obtain material for DNA analysis of 16 of the 17 genera of Prance \& White (1988) and was only missing Parastemon whereas all previous molecular studies placing the Chrysobalanaceae in the Malpighiales had been based on material of only two or three genera. Dichapetalum and Euphronia were both used as outgroups by Yakandawala. This study indicated a molecularly well-defined monophyletic family that is sister to Euphronia, and it showed that the tribal arrangement of Prance \& White (1988) was paraphyletic. Figure 11 shows the Bayesian consensus tree from the combined analysis of Yakandawala. The abbreviations on the right-hand side stand for the four tribes of Prance \& White (1988) and it shows how paraphyletic they were. Some of the subclades in this cladogram are interesting. The genera formerly placed in Parinari are spread throughout with Atuna being basal. The three genera with a staminal ligule, Acioa, Dactyladenia and Kostermanthus are in the same subclade, and an interesting clade has Exellodendron and Hunga together, an association that has reappeared in our later molecular work.

More recently I have been collaborating with two groups working on the molecular genetics of the Chrysobalanaceae: Jérôme Chave, his student Léa Bardon and others at 


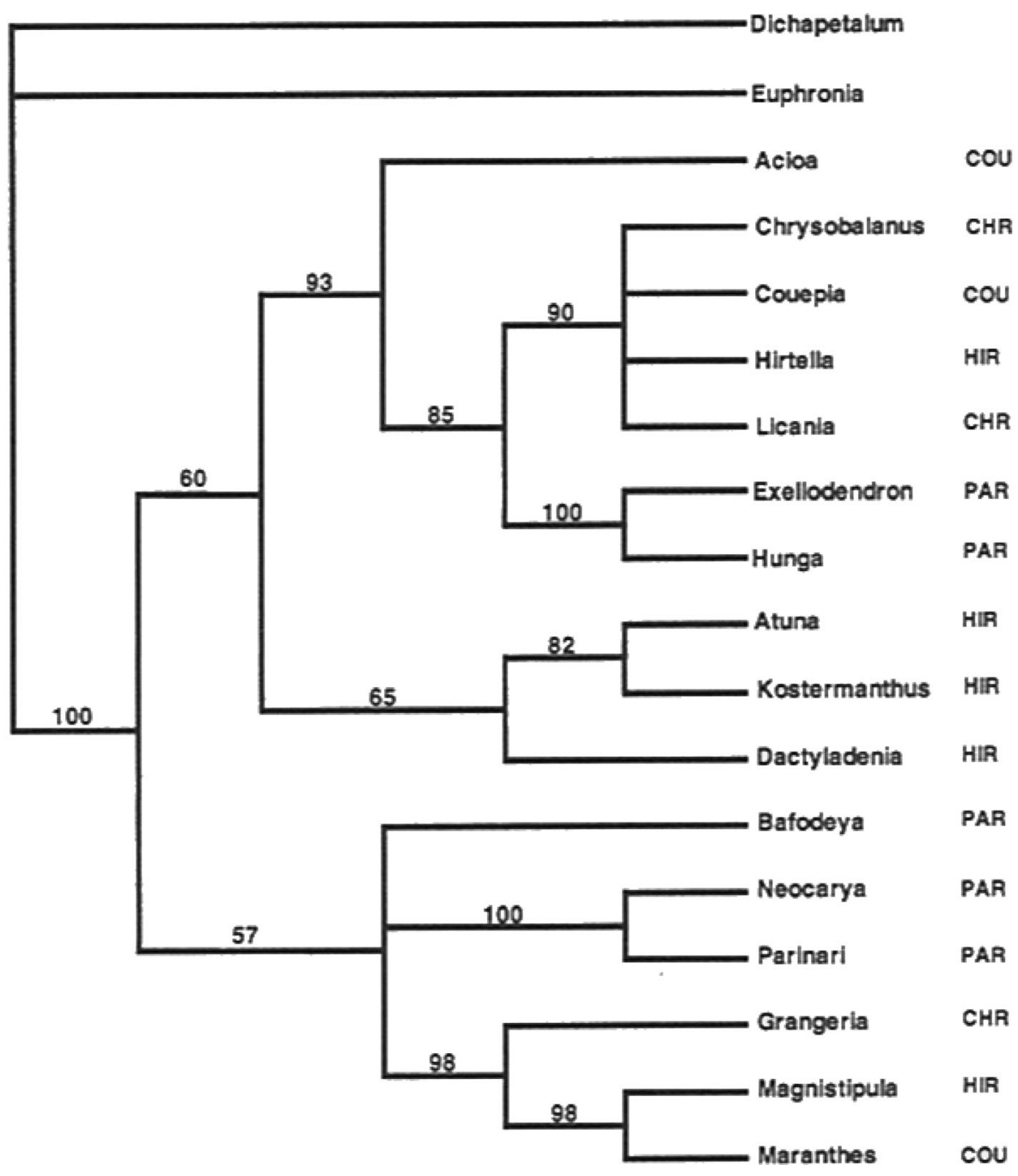

Fig. 11 One of the cladograms from the analysis of Chrysobalanaceae by Yakandawala et al. (2010). The righthand column represents the tribal assignment in Prance \& White (1988): CHR = Chrysobalaneae; COU = Couepieae; HIR = Hirtelleae; $\mathrm{PAR}=$ Parinarieae, an indication that these tribes are polyphyletic

Université Paul Sabatier in Toulouse (Bardon et al., 2012, 2016) and Cynthia Sothers, Mark Chase and others in the Jodrell Laboratory at Kew (Sothers et al., 2014, 2016). The work of both groups was only possible because of the existence of detailed monographs (Prance, 1972a, 1979; Prance \& Sothers, 2003a, 2003b) as a basis to test their evolutionary hypotheses. The Toulouse group have concentrated on ancestral state reconstruction and on the biogeography of speciation over time and the Kew group more on producing a monophyletic classification of the family. These studies demonstrated a lot of paraphyly in the generic concepts and tribes of Prance \& Sothers. The first molecular study of Sothers concentrated on the genus Couepia (Figs. 12, 13). It clearly showed that Couepia was polyphyletic and taxonomically it resulted in 


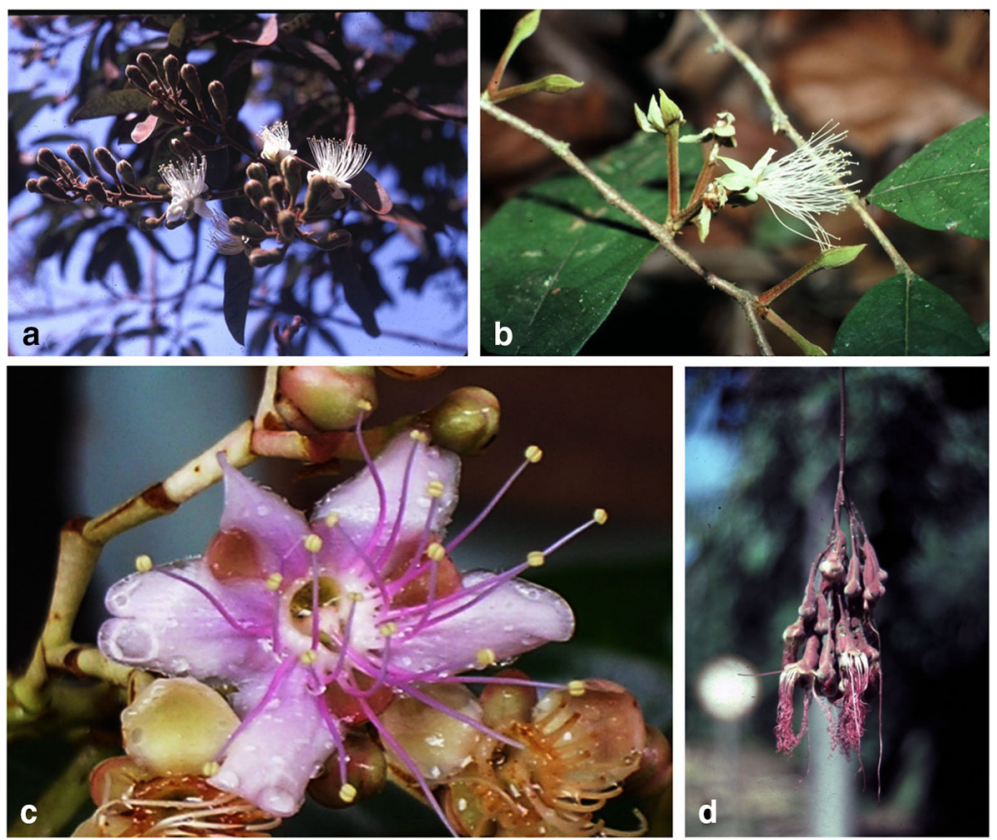

Fig. 12 Couepia and the segregates from it. a Couepia grandiflora (Mart. \& Zucc.) Benth. ex Hook. f. b Gaulletia parillo (DC.) Sothers \& Prance. c Acioa edulis Prance. d Acioa longipendula (Pilg.) Sothers \& Prance

describing the small genus Gaulettia for a group of nine species mainly in white-sands areas of the Amazon and Guianas, and the transference of Couepia recurva Spruce ex Prance to Hirtella, of Couepia platycalyx Cuatrec. to Licania and of Couepia longipendula Pilg. and C. dolichopoda Prance to Acioa (Fig. 13 and Table 3). Four of the species now in Gaulletia were already grouped together into the Couepia parillo superspecies by Prance (1972a). The placement of Couepia platycalyx has always been difficult on morphological grounds as it shares characters in common with both Couepia and Licania. Cuatrecasas (1950) when he described this species called it an "extraordinary member of Couepia" because of its flat, solid receptacle. In Prance (1972a) I also expressed doubts about its affinity because of the rather different ovary and fruit. At that time there were only two specimens available for study. Now there are many collections of $C$. platycalyx available and plus many more of other species of Licania, so after further molecular work we decided that C. platycalyx is best treated as a monospecific genus that we named as Cordillera in Sothers et al. (2016) after its montane ecology. We now know that Cordillera platycalyx (Cuatrec.) Sothers \& Prance is quite widespread ranging from Costa Rica and Panama through Colombia to Ecuador, usually in highland forests from 1000 to $2500 \mathrm{~m}$ altitude. The two species transferred to Acioa have also always been regarded as distinct within Couepia as both have reddish flowers and are bat-pollinated, as opposed to most other species of Couepia which have white flowers and are moth- or bee-pollinated. Although both lack the traditionally defining character of stamens fused into a ligule, they share many other characters with the genus Acioa. 


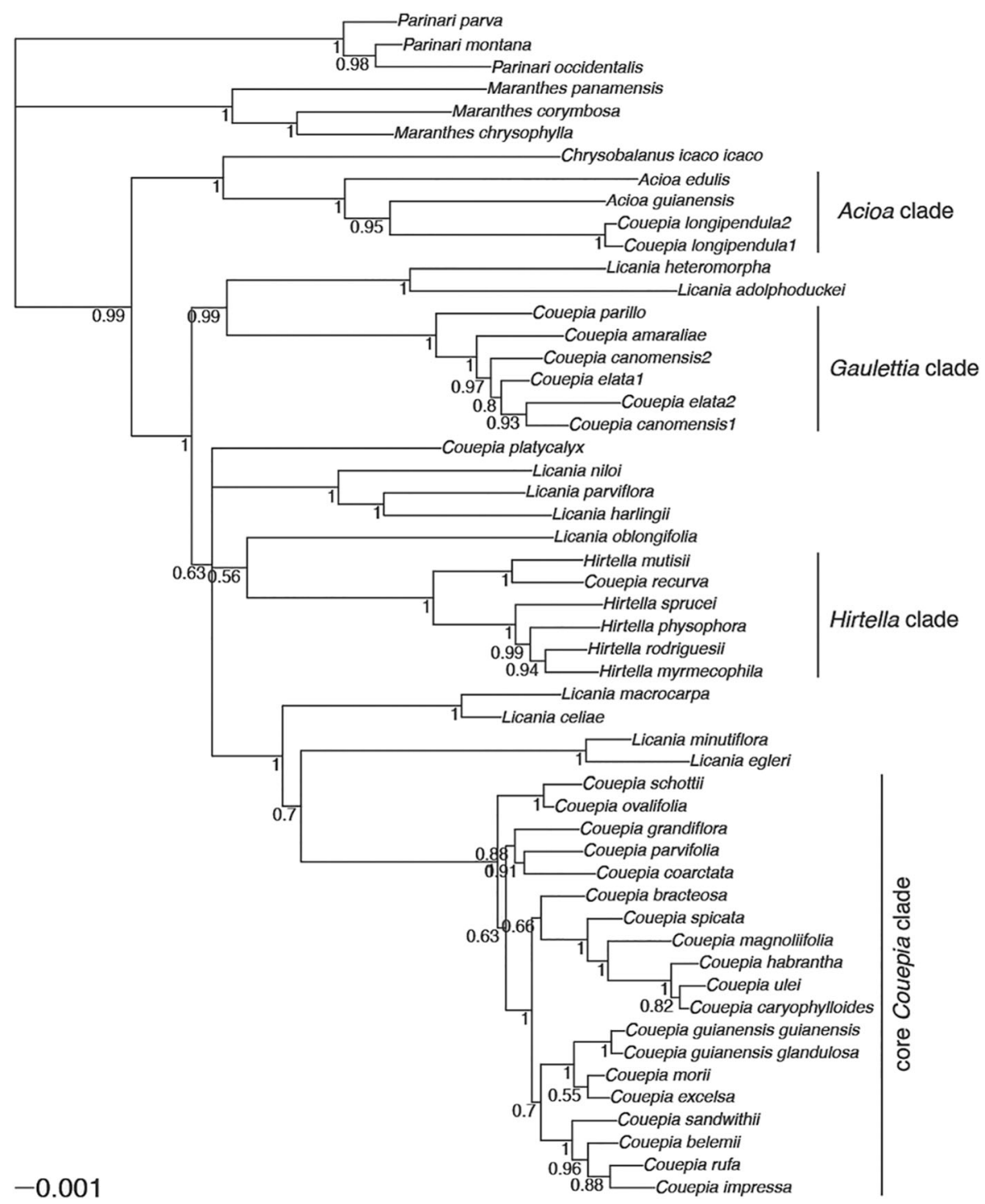

Fig. 13 A combined Bayesian half-compatible phylogenetic tree of Couepia and sister lineages from Sothers et al. (2014). The outgroup Euphronia not shown due to its long branch length. This shows the species removed from Couepia to the new genus Gaullettia and that Couepia recurva is sister to a species of Hirtella and is now Hirtella recurva (Spruce ex Prance) Sothers \& Prance. Used with the permission of Cynthia Sothers

An important aspect of the molecular work is the determination of the basal genus of the family and its evolutionary history over time. The early diverging genera have varied slightly from one analysis to another and is still rather uncertain at present, In Bardon et al. (2016) Kostermanthus from Malesia was early diverging and Neocarya and Parinari sister to it. In Sothers et al. (2016) the monospecific West African genus Neocarya was basal with Parinari sister to it. but it seems that Neocarya, Bafodeya, Parinari and Kostermanthus are near to the base. The Toulouse group (Chave et al. in 
press) are working on a dated phylogeny based on the plastid genome that dates the family back to the late Miocene. The family appears to have originated in the Paleotropics followed by a rapid diversification in the Neotropics at a much later date. In this new analysis based on plastomes Kostermanthus and Bafodeya are recovered as the earliest diverging genera.

This review concentrates on the generic boundaries of the Chrysobalanaceae, and there is much more information beyond that in the papers from both groups (Bardon et al., 2012, 2016, Chave et al., in press, Sothers et al., 2014, 2016), These papers contain the cladograms involved (Figs. 14, 15 and 16). The splitting up of Parinari by Prance \& White (1988) is confirmed by the molecular work and the pantropical Parinari sens. Strict. holds together well. In Sothers et al. (2016) we published the

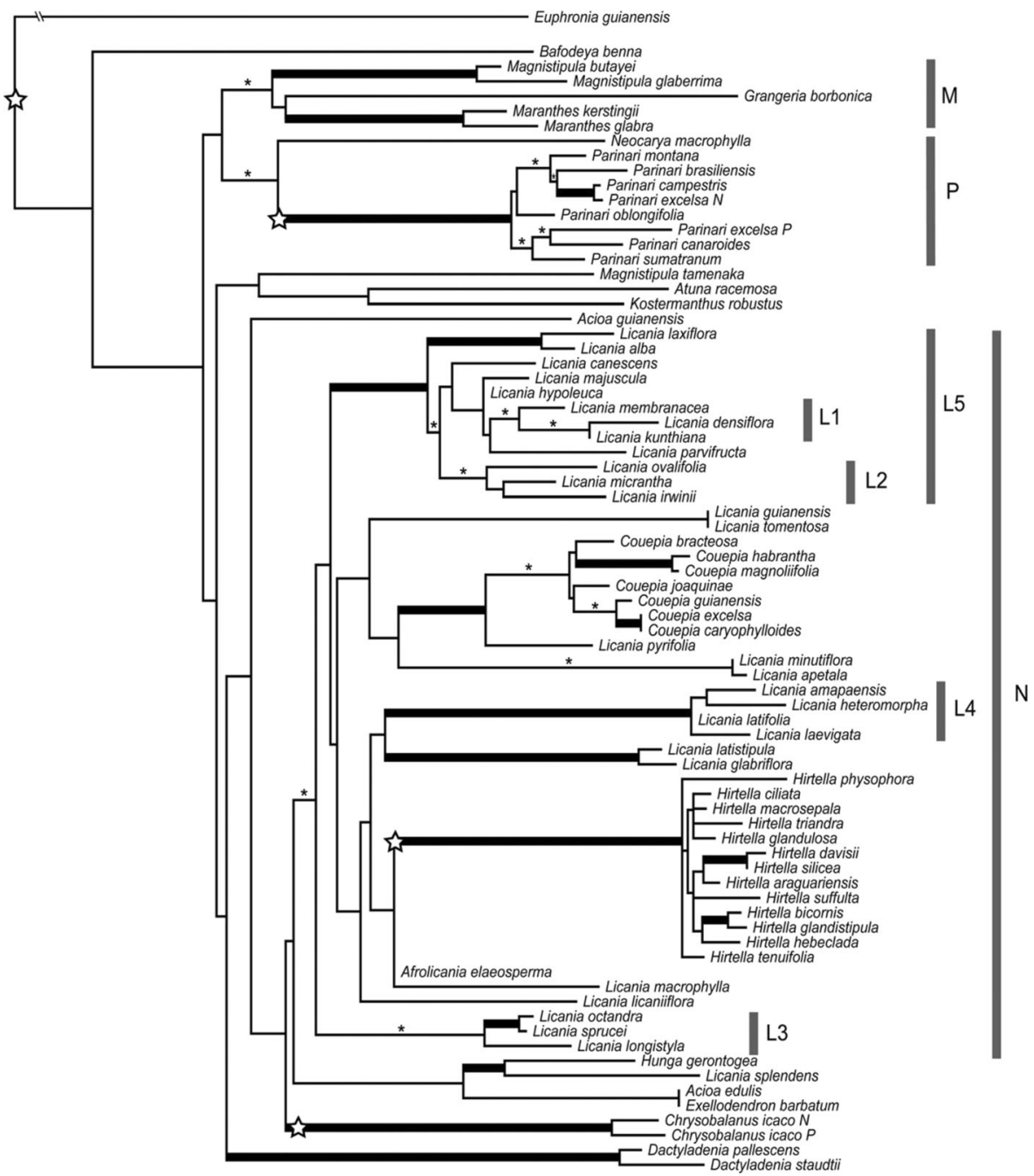

Fig. 14 A phylogenetic tree of Chrysobalanaceae from plastid plus nuclear markers, from Bardon et al. (2012). Branches supported by bootstrap values $>80 \%$ are thick and those with bootstrap values $60-80 \%$ marked by an asterisk. This tree included here to show how Licania sens.lat. is obviously not monophyletic 


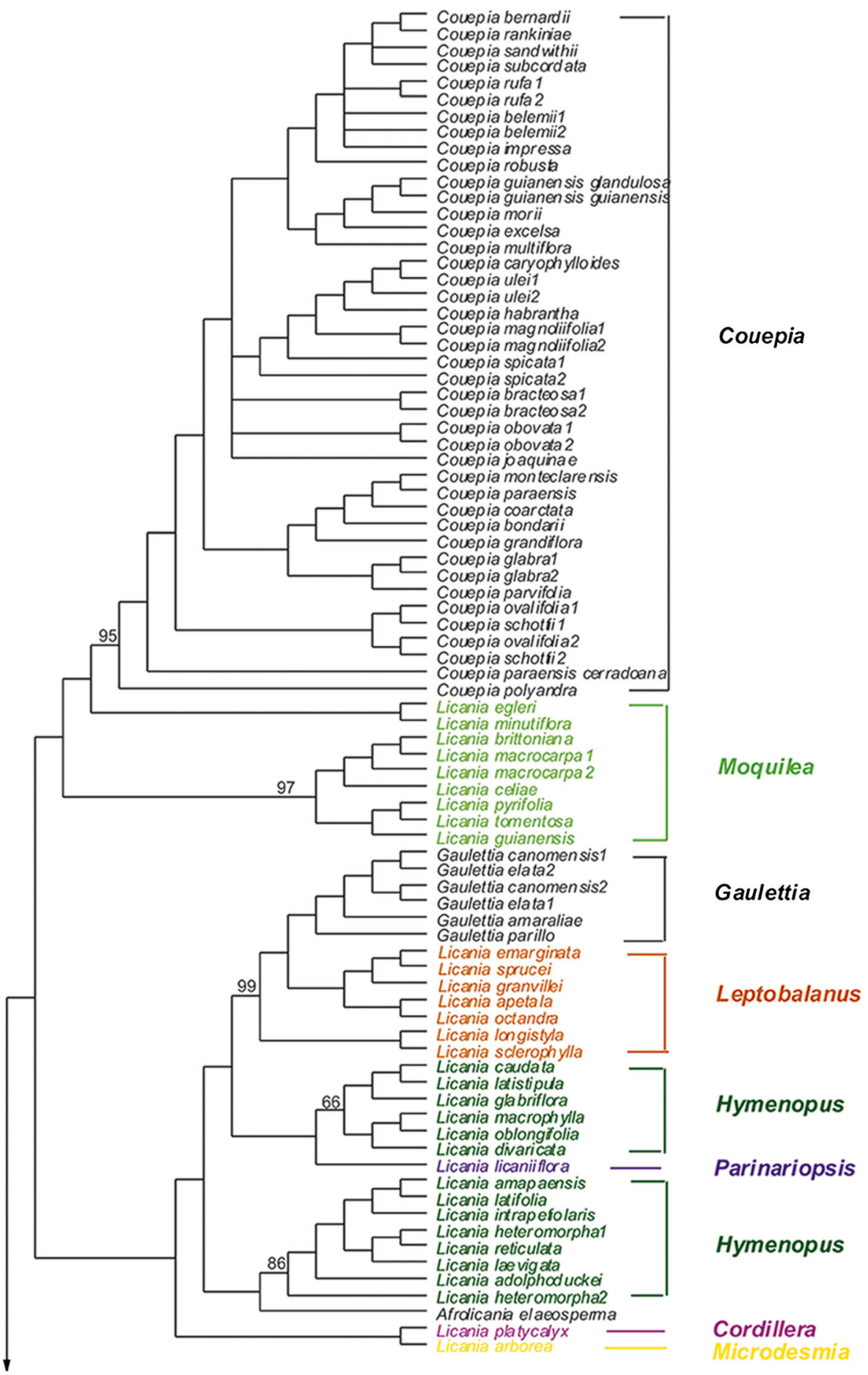

Fig. 15-16 Strict consensus tree of the combined analysis (plastid, ITS and Xdh), highlighting clades with taxa of Licania s.l. and the new generic names; bootstrap support is shown above branches. Clades of all other Neotropical genera and the outgroup are also cited. (from Sothers et al., 2016). Used with the permission of Cynthia Sothers 

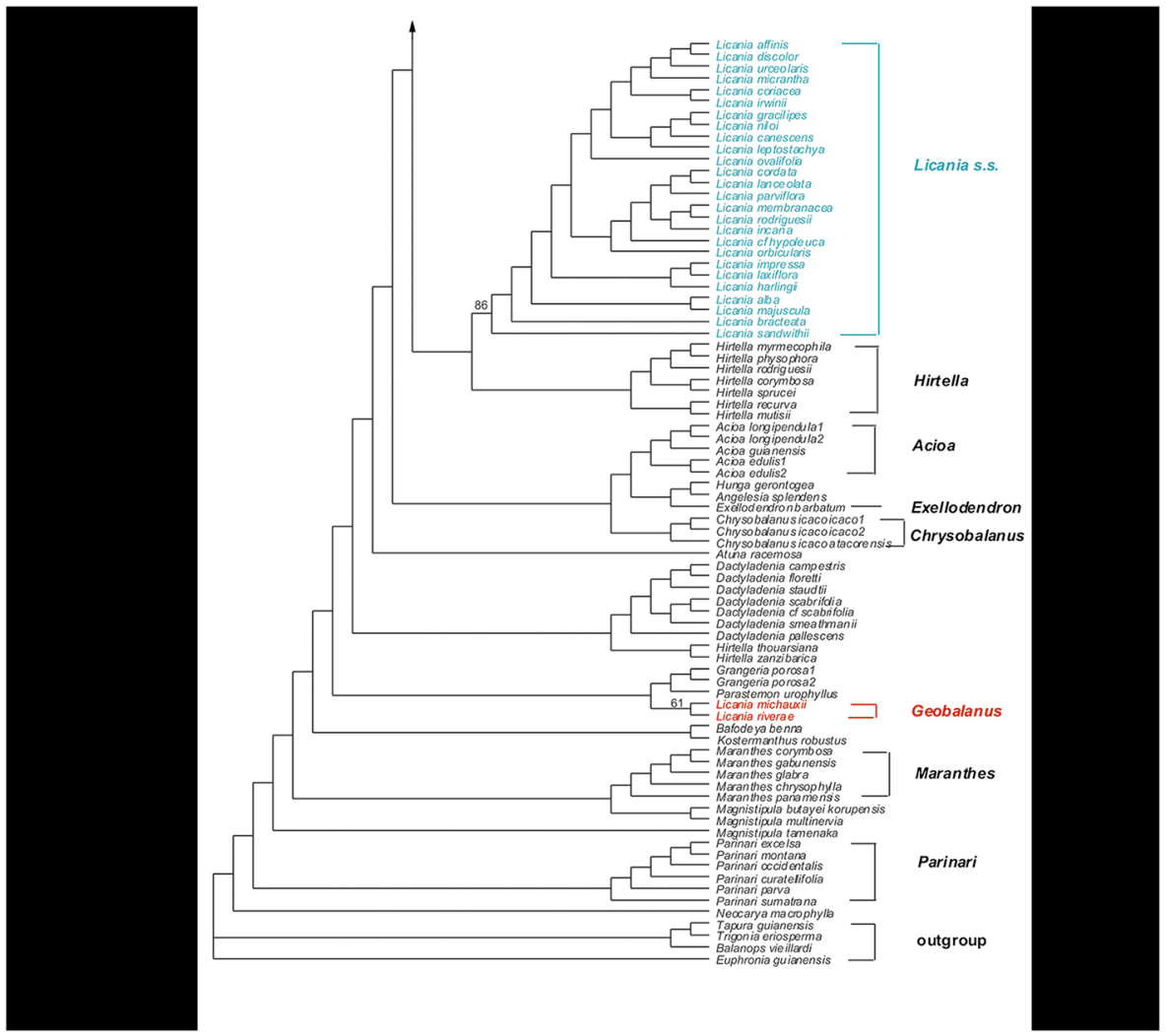

Fig. 15-16 (continued)

division of Licania into nine genera that complied with the phylogeny indicated by the molecular studies of both the Kew and the Toulouse researchers (Table 5). Most of these new genera split from Licania were actually recognised in Prance (1972a) as subgenera or sections of Licania (Table 4). While they were distinguished there by morphology, the relationships were not then evident and so they were all lumped together in the paraphyletic genus LIcania. The genera split from Licania are briefly mentioned here but are described in more detail in Sothers et al. (2016) together identification keys and the necessary nomenclatural changes.

Table 4 The subdivisions of Licania recognized in Prance (1972a)

\begin{tabular}{lll}
\hline Subgen. Moquilea (Aubl.) Prance & subgen. Licania & Subgen. Parinariopsis Huber \\
\hline Section Moquilea & Section Licania \\
Section Leptobalanus Benth. & Section Hirsuta Prance \\
Section Microdesmia Benth. & Section Hymenopus Benth. \\
& Section Cymosa Prance \\
& Section Pulverulenta Prance
\end{tabular}


Afrolicania and Angelesia were both originally described as distinct genera but later submerged into Licania (White, 1976, Fritsch, 1899). Afrolicania, described by Mildbraed (1921) for specimens from Cameroon, has had a varied history. It is obviously closely related to the Neotropical Licania as its name suggests and it is obviously the result of an ancient transoceanic dispersal. The morphology is so similar to Licania that in Prance \& White (1988) we merged it with Licania following the opinion of White (1976). In Prance and Sothers (2003a) we re-established the genus largely based on the molecular and cladistic data of Dissanayake 1999, (published as Yakandawala et al., 2001, 2010), and this has been confirmed in our later molecular work. Angelesia has also had an uncertain history. This genus of three species from Malesia was described by Korthals (1855) and in the same year Blume (1855) proposed transferring it to Licania with the illegitimate name Licania angelesia Blume. Angelesia was generally accepted as a genus until Hallier (1903) suggested merging Moquilea and Angelesia with Licania. This merger was accepted by Prance (1988). Thus, the concept of Licania in Prance \& White (1988) was of a pantropical genus including Angelesia and Afrolicania. Our molecular data have shown clearly that Angelesia is better treated as a distinct genus and it was resurrected in Sothers and Prance (2014) and so once again Licania became an exclusively Neotropical genus.

Geobalanus is a small genus that was described for two species from Florida and Georgia by Small (1913), one of which he transferred from Chrysobalanus oblongifolius Michaux (1803) to his new genus. Prance (1972a) and Prance (1988) treated Geobalanus as a synonym of Licania. In our molecular work Geobalanus appears as an early diverging genus sister to Parastemon from Malesia and Grangeria from Madagascar, but this position lacked strong support and its true position is sister to the large clade including most Neotropical genera. In Sothers et al. (2016) we recognized Geobalanus as distinct and added a third species, G. retifolius (S.F. Blake) Sothers \& Prance from Mexico, transferred from Licania.

Moquilea was first described as a genus by Aublet (1775) at the same time as Licania. It was recognised as a genus through most of the nineteenth century, for example by Hooker (1865), although Grisebach (1857) merged it with Licania. This merger was followed by several later workers including Fritsch (1899) in his Conspectus generis Licaniae. More details of this varying history were given in Prance (1972a) who also placed Moquilea as a synonym of Licania. In Sothers et al. (2016) we recognised Moquilea as a genus because in all our molecular analyses it was consistently retrieved as sister to Couepia in a separate lineage rather than in a position close to Licania. Moquilea now consists of 54 species ranging from Mexico and Central America and the Caribbean to Bolivia and southern Brazil.

There was another group of 31 species of Licania placed in subgenus Moquilea because of their exserted stamens but placed in a distinct section Leptobalanus by Bentham (1840) because of being apetalous as is the case in core Licania. This section was also recognized in Prance (1972a) \& Sothers \& Prance (2003a). In the molecular analysis Leptobalanus was retrieved as a distinct clade sister to Gaulettia in a larger clade together with Hymenopus, Cordillera and Microdesmia. To achieve monophyly Leptobalanus was elevated to generic rank in Sothers et al. (2016) and its true position is as sister to Licania sens. Str.

The placement of Licania licaniiflora (Sagot) Blake was always a problem for me. It was first described in Moquilea by Sagot (1883) and it also has many synonyms in 
Licania, see Prance (1972a) where I recognized Huber's (1909) Licania subgenus Parinariopsis for this species. L. licaniiflora differs from Licania and the other segregate genera by the ovary inserted on the middle of the receptacle tube, and in the pairs of bracts enclosing the flower buds as occurs in Parinari. It lacks strong support in our molecular work and so in Prance and Sothers et al. (2016) we recognized it as the monospecific genus Parinariopsis. It is a widespread species of river and savanna margins in Venezuela, the Guianas and the eastern Amazonian region.

Two closely related species Licania arborea Seem. from Mexico, Central America and western South America and L. rigida Benth. from the caatingas of northeast Brazil were sufficiently different from the rest of Licania to be placed in subgenus Microdesmia by Bentham (1840). The seeds of both species yield a quick drying oil used in paints, soaps and candles. In Prance (1972a) I placed six other species in subgenus Microdesmia together with the original two of Bentham and three more were added in Sothers and Prance (2003a), but we always regarded this as a temporary artificial group. Other than Licania arborea and L. rigida seven of the species formerly in subgenus Microdesmia have since been transferred to Moquilea and one to Hymenopus (Sothers et al., 2016). The remaining two species of subgenus Microdesmia were sister to Cordillera and not close to Licania in the molecular work and so to accommodate $L$. arborea and $L$ rigida it was necessary to elevate the subgenus of Bentham to generic status as Microdesmia containing just two species.

Section Hymenopus of Licania was also elevated to generic status in Sothers et al. (2016). It contains twenty-eight species distributed in Central America and Trinidad and throughout lowland northern South America and Amazonian Brazil. The presence of petals and the glabrous leaves distinguish it from Licania sens. str. and indeed it is well separated from Licania in the molecular work. At present Hymenopus is retrieved in two nearby subclades. In Sothers \& Prance we chose to maintain these subclades as a single genus, but there is room for future studies in this area. The work discussed above has split Licania into nine genera, but Licania sens. str. still remains the second largest genus in the family with 100 species, exceeded only by Hirtella with 107.

The splitting up of Parinari, Couepia and Licania each into several separate genera in the course of the work discussed above is summarised in Table 5. The fifteen genera

Table 5 The 28 genera reflecting a monophyletic arrangement of Chrysobalanaceae, resulting from the molecular studies of Bardon et al. $(2012,2016)$ and Sothers et al. (2014, 2016). Columns 1-3 list the genera that were previously placed in the genus at the top that is in bold face. Full details and descriptions of the new genera are in Sothers \& Prance (2016)

\begin{tabular}{|c|c|c|c|}
\hline Parinari & Licania & Couepia & \\
\hline Atuna & Afrolicania & Gaulettia & Magnistipula \\
\hline Bafodeya & Geobalanus & Cordillera & Dactyladenia \\
\hline Exellodendron & Leptobalanus & & Acioa \\
\hline Kostermanthus & Moquilea & & Grangeria \\
\hline Hunga & Hymenopus & & Parastemon \\
\hline Maranthes & Parinariopsis & & Hirtella \\
\hline \multirow[t]{2}{*}{ Neocarya } & Microdesmia & & Thelira \\
\hline & Angelesia & & Chrysobalanus \\
\hline
\end{tabular}


that I started with (Table 1) are now twenty-eight (Table 5) and two of the original genera Lecostemon and Stylobasium are no longer placed in or near to the Chrysobalanaceae.

\section{The Future}

The genera of the Chrysobalanaceae are now well resolved and are mainly monophyletic, but there still remains a lot to be done at specific rank sorting out some of the species complexes with more extensive molecular work. Some of the groups about which I still have doubts in the taxonomy and that can only be resolved by further study of the DNA of a lot of samples are listed below, hopefully to stimulate further research.

Chrysobalanus icaco L. This transoceanic species has considerable variation in leaf size and shape as well as the color of the fruit. I have maintained this as one rather polymorphic species as there is little link between the character variation and either locality or habitat. There have been several attempts to study this variation, for example Paracampo et al. (2017), Paracampo et al. (2020), but while showing some correlation between fruit color and habitat they have come to no taxonomic conclusions.

Hirtella racemosa Lam. is a complicated and widespread species ranging from Mexico to southern Brazil. At present I recognize three varieties of this species, but still feel that the taxonomy is not yet resolved.

Hymenopus (Licania) heteromorphus (Benth.) Sothers \& Prance. Even after the new species I have separated out of this complex there still remains a great deal of morphological variation and habitat choices from which it is hard to define further taxa. The genus Hymenopus itself still needs further study as it appears in two separate clades in the molecular work.

Leptobalanus (Licania) apetalus (E. Mey.) Sothers \& Prance. At present I recognize two varieties of this widespread mainly riverine species, but I am convinced that it needs further splitting at the infraspecific level.

Part of the former Licania section Microdesmia is a taxon the composition of which I was quite uncertain in Prance (1972a). While $L$ rigida and $L$. arborea have been retained in what is now a monophyletic genus Microdesmia, I am less certain about the other six species that we transferred to Moquilea in Sothers et al. (2016). This is still a group of little-collected species that are in need of further study.

In Africa White (1976) treated seven former species as subspecies of Magnistipula butayei De Wild. The definitions of some of these taxa are still vague and this group merits a thorough molecular study.

In Asia Atuna excelsa (Jack) Kostermans would merit further study. In this wideranging species from Malaysia to Samoa I have recognised two subspecies (Prance, 1989b, 2019), but feel that a molecular study would be useful both to either confirm or refute the taxonomy and to help to determine whether the distribution of this most useful species is natural oceanic dispersal or mediated by humans.

The most exciting challenge for future work with the Chrysobalanacae lies with phylogenomics which is the next generation of sequencing techniques. This may be used to resolve some of the species complexes mentioned above and could produce an even more accurate evolutionary system for the family. 
There are still a large number of species of Chrysobalanacaeae known only from one or two specimens. It would be important and interesting to look at the species that have not been seen for the last fifty or more years to ascertain their appropriate conservation status and whether they are still extant.

\section{Conclusions}

Perhaps the most obvious conclusion from this review is that one should not necessarily stick with one's original taxonomic conclusions. Many of my original decisions about generic boundaries based on morphology had to be modified along the way as new data were accumulated and new methods applied. It is important to aim for rigorous systems that do not include polyphyletic taxa and so many changes to the generic concepts of the Chrysobalanaceae have been made to achieve this. Detailed monographs of large tropical groups form the basis for many other studies such as the molecular work discussed above as well as for much ecological work and by providing much of the information on which to plan conservation. An important spin-off from monographic work is that it makes local floras more accurate because they are based on more complete surveys of a plant family far beyond the area covered by the flora. The second part of the references below lists the twenty-three floras and checklist projects involving the Chrysobalanaceae to which I have contributed both in the neotropics and in Malesia.

Supplementary Information The online version contains supplementary material available at https://doi.org/ 10.1007/s12229-020-09234-y.

Acknowledgements Firstly, I am most grateful to the four institutions and herbaria that have made this study and my career possible: The Forest Herbarium of Oxford University (FHO), The New York Botanical Garden (NY), the Instituto Nacional de Pesquisas da Amazônia, (INPA) in Manaus, and the Royal Botanic Gardens, Kew (K). I especially thank the late Frank White who first pointed me towards the Chrysobalanaceae as a possible thesis project and then worked with me on the family for many years. During my doctoral studies I am most grateful to some of the distinguished botanists at Kew and BM who spent much time mentoring a young visiting graduate student, especially, Arthur Exell and William Stearn (BM), and Noel Sandwith, Nigel Hepper and Leonard Forman (K). Thank you to Bassett Maguire and Howard Irwin who connected me to The New York Botanical Garden and gave me much encouragement over the years. I thank my three patient administrative assistants who typed many manuscripts and processed much data: Mickey Maroncelli at The New York Botanical Garden and Pauline Churcher and Eleanor Bunnell at Kew. The fieldwork for the study of Chrysobalanaceae and other groups would not have been possible without the financial support of the National Science Foundation and the assistance of various field assistants, especially José Ramos, Dionísio and Luis Coêlho, Osmarino Monteiro, Bento S. Pena and Nilo T. da Silva. At INPA in Manaus I have been much helped over the years by William A. Rodrigues, Marlene F. da Silva, Michael J. G. Hopkins and Bruce W. Nelson. During the past two-and-a-half decades it has been a pleasure to collaborate with Cynthia Sothers whom I first met in 1995 when we were working together on the Chrysobalanaceae for the Flora of the Ducke Forest Reserve near to Manaus, Brazil. Her later molecular work has contributed much to achieving monophyly in the Chrysobalanaceae. In addition to the above I have collaborated scientifically with many other people and I particularly thank Mark Chase, Jérôme Chave, Michael Fay, Deepthi Dissanayake and Cynthia Morton for their interest in the Chrysobalanaceae. I especially thank my wife Anne who accompanied me to Brazil many times, organised the field base, looked after sick botanists and has patiently tolerated all the time I have devoted to study of the Chrysobalanaceae. I am extremely grateful to the International Cosmos Prize for providing the funds that enable me to continue research long into official retirement. I thank Martin Cheek for commenting on an earlier draft of this paper and Douglas Daly for a helpful review of this manuscript. 
Open Access This article is licensed under a Creative Commons Attribution 4.0 International License, which permits use, sharing, adaptation, distribution and reproduction in any medium or format, as long as you give appropriate credit to the original author(s) and the source, provide a link to the Creative Commons licence, and indicate if changes were made. The images or other third party material in this article are included in the article's Creative Commons licence, unless indicated otherwise in a credit line to the material. If material is not included in the article's Creative Commons licence and your intended use is not permitted by statutory regulation or exceeds the permitted use, you will need to obtain permission directly from the copyright holder. To view a copy of this licence, visit http://creativecommons.org/licenses/by/4.0/.

\section{References and Publications on Chrysobalanaceae}

The citations below include all the publications of G. T. Prance and collaborators on the Chrysobalanaceae, some of which are not cited in the text, as well as all of the references from other people cited in the text (n.d.).

\section{Monographs}

S.A. Mori \& G. T. Prance 1990, The Zygomorphic-flowered New World Lecythidaceae. Lecythidaceae - Part Ii. flora Neotropica Monograph 21 (2): 1-376. NY Botanical Garden Press.

Prance, G. T. 1972a. Chrysobalanaceae: Flora Neotropica Monograph 9, 1-409. Hafner, New York.

Prance, G. T. 1972b. Dichapetalaceae: Flora Neotropica Monograph 10, 1-84. Hafner, New York.

Prance, G. T. 1973a. Caryocaraceae: Flora Neotropica Monograph 12, 1-75, Hafner, New York.

Prance, G. T. \& S. A. Mori. 1979. The Actinomorphic-flowered New World Lecythidaceae. LecythidaceaePart I. flora Neotropica Monograph 21: 1-270. New York Botanical Garden Press.

Prance, G. T. 1989a. Chrysobalanaceae: Flora Neotropica Monograph 9S, 1-267. New York Botanical Garden Press.

Prance, G. T. 2018, Rhizophoraceae: Flora Neotropica Monograph 120, 63 pages. 2018. NY Botanical Garden Press.

Prance, G. T. K. S. Edwards, V. Plana \& R. T. Pennington. 2008. Proteaceae. Flora Neotropica Monograph 100, 250 pages. 2008. New York Botanical Garden Press.

Prance, G. T. \& C.A. Sothers 2003a. Chrysobalanaceae 1: Chrysobalanus to Parinari. Species Plantarum, Flora of the World 9: 1-201.

Prance, G. T. \& C.A. Sothers 2003b. Chrysobalanaceae 2: Acioa to Magnistipula. Species Plantarum, Flora of the World 10: 1-268.

\section{Floras and Checklists}

Leite El Ottra, J.H., J. R. Pirani \& G. T. Prance 2008. Chrysobalanaceae. In Flora da Serra do Cipó, Minas Gerais. Bol. Bot. Univ. São Paulo 26: 155-160.

Prance, G. T. 1979. Chrysobalanaceae. Flora of Ecuador 10: 1-23.

Prance, G. T. 1982. Chrysobalanaceae Flora de Venezuela 14(2): 325-487.

Prance, G. T. 1983. Chrysobalanaceae. Fl. Nouvelle-Calédonie et Dépendances 12: 105-123.

Prance, G. T. 1986. Chrysobalanaceae. Flora of the Guianas: 85: 1-146.

Prance, G. T. 1988. Chrysobalanaceae: Flora do Estado de Goiás Rizzo 10: 1-62.

Prance, G. T. 1989b. Chrysobalanaceae. Flora Malesiana Ser. 1.10: 635-678.

Prance, G. T. 1995. Chrysobalanaceae. pp. 155-179. In: E. Soepadmo \& K.M. Wong. Tree Flora of Sabah \& Sarawak, Kuala Lumpur, Malaysia.

Prance, G. T. 1998a. Chrysobalanaceae. pp. 202-246. In: J.A. Steyermark, P.E. Berry \& B.K. Holst (eds.). Flora of the Venezuelan Guyana 4.

Prance, G. T. 1998b. Chrysobalanaceae. pp. 31-32 In: S. Cable \& M. Cheek (eds.). The plants of Mount Cameroon: a conservation checklist. Royal Botanic Gardens, Kew. 
Prance, G. T. 1999. Chrysobalanaceae, pp. 395-398 in P.M. Jørgensen \& S. León-Yánez (eds,) Catalogue of the vascular Plants of Ecuador. Missouri Bot. Gard. Press.

Prance, G. T. 2001a. Chrysobalanaceae, In: W.D. Stevens, C. Ulloa Ulloa, A. Pool \& O.M. Montiel (eds.) Flora de Nicaragua, Monogr. Syst. Bot. Missouri Bot. Gard. 85 (1): 606-616.

Prance, G. T. 2001b. Chrysobalanaceae. Flora de Colombia 19: 1-292.

Prance, G. T. 2002. Chrysobalanaceae. pp. 202-212 In: S. A. Mori et al. (Eds.) Guide to the vascular plants of French Guiana, Part 2. Dicotyledons. New York Botanical Garden Press.

Prance, G. T. 2003a. Chrysobalanaceae. pp. 180-189. In: P. S. Ashton, A. S. Kamariah \& I. Md. Said. A Field Guide to the forest trees of Brunei Darussalam Vol 1.

Prance, G. T. 2003b. Chrysobalanaceae. In M.G.L. Wanderley et al. (eds.) Flora Fanerogâmica do Estado de São Paulo. 3: 33-44.

Prance, G. T. 2008a. Chrysobalanaceae Pp 1930-31, In: F. O. Zuloaga, O. Morrone \& M. J. Belgrano (eds.) Catálogo de las Plantas Vasculares del Cono Sur, Vol. 2.

Prance, G. T. 2008b. Chrysobalanaceae pp. 168-173, In: D. C. Daly \& M. Silveira (eds.). Primeiro catálogo da Flora do Acre, Brasil, Univ. Federal do Acre, Rio Branco.

Prance, G. T. \& C.A. Sothers 2010. Chrysobalanaceae In Lista de Espécies da Flora do Brasil, Jardim Botânico do Rio de Janeiro (http://floradobrasil.jbrj.gov.br/2010/FB000085). And Catálogo de plantas e fungos do Brasil 1: 847-856.

Prance, G. T. \& C.A. Sothers 2009. Chrysobalanaceae. Neotropikey, www.kew.org/science/tropamerica/ neotropikey/families/Chrysobalanaceae.htm

Prance, G. T. 2012. Chrysobalanaceae. Flora of Peninsular Malaysia 3: 13-46, 335.

Prance, G. T. \& M. Moraes. 2015. Chrysobalanaceae, In: PM Jorgensen et al. (eds.) Catálogo de las Plantas Vasculares de Bolivia: 503-507.

Prance, G. T., T. C. Whitmore 1973. Chrysobalanaceae in Tree Flora of Malaysia 2: 321-340.

Sothers, C.A. \& G.T. Prance 1999. Chrysobalanaceae. Pp 345-359. In: J. E. L. da S. Ribeiro et al. Flora da Reserva Ducke: Guia de identificação das plantas vasculares de uma floresta de terra-firme na Amazônia Central. Manaus, INPA.

\section{Reviewed Papers and General References}

Agardh, J. G. 1858. Stylobasieae, in: Theoria systematis plantarum: 169.

APG. 1998. An ordinal classification of the families of flowering plants. Ann. Missouri Bot. Gard. 85: 531553.

APG IV. 2016. An update of the Angiosperm Phylogeny Group classification for the orders and families of flowering plants: APG IV. J. Linn. Soc., Bot. 181: 1-20.

Aublet, F. 1775. Histoire des plantes de la Guiane français 1: 119, 521.

Bardon, L., J. Champagne, K. G. Dexter, C. A. Sothers, G. T. Prance \& J. Chave. 2012 Origin and evolution of Chrysobalanaceae: insights into the evolution of plants in the Neotropics. J. Linn. Soc., Bot. 171: 1937.

Bardon, L., C. Sothers, G.T. Prance, P.-J Male, Z. Xi, C.C. Davis, J. Murienne, R. Garcia-Villacorta, E. Coissac, S. Lavergne \& J. Chave. 2016. Unravelling the biogeographic history of Chrysobalanaceae from plastid genomes. Amer. J. Bot. 102.1089-1102.

Beck, H.T \& G.T. Prance 1992. Ethnobotanical note on Marajó ceramic pottery utilizing caripé (Licania octandra ssp. octandra) and jutai (Hymenaea oblongifolia var. palustris). Bol. Mus. Paraense Hist. Nat., Bot. 7: 269-275.

Bentham, G. 1840. Contributions towards a flora of South America XII. Enumeration of plants collected by Mr. Schomburgk in British Guiana. J. Bot. (Hooker) 2: 210-222.

Bentham, G. 1853. Notes on two little-known genera connected with South America. Hooker's. J. Bot. Kew Gard. Misc. 5: 289-296.

Berlin, B. \& G.T. Prance 1978. Insect galls and human ornamentation: The Ethnobotanical significance of a new species of Licania from Amazonas, Peru. Biotropica 10: 81-96.

Blume C. 1825. Bijdr. Fl. Ned. Ind.: 89. Batavia.

Blume C. 1855. Mélanges Botaniques 2: 9-12.

Brown, R. 1818. Chrysobalanaceae. In: Appendix 5, Tuckey, Capt. J. K. Narrative of an expedition to explore the River Zaire. 433-434. London.

Carnevale Neto, F., A.C. Pilon, V Da S. Bolzani \& I Castro-Gamboa, 2013. Chrysobalanaceae: secondary metabolites, ethnopharmacology and pharmacological potential. Phytochem. Review 12: 121-146. 
Chase, M. W. and 41 other authors. 1993. Phylogenetics of seed plants: an analysis of nucleotide sequences from the plastid gene rbcL. Ann. Missouri Bot. Gard. 80: 528-580.

Chave, J., C.A. Sothers, A. Iribar. U. Suescun, M.W. Chase \& G.T. Prance, 2020. Rapid diversification rates in Amazonian Chrysobalanaceae inferred from plastid genome phylogenetics. J. Linn. Soc., Bot. XX: 119. https://doi.org/10.1093/botlinnean/boaa052

Coradin, L., D.E. Giannasi \& G.T. Prance, 1985. Chemosystematic studies in the Chrysobalanaceae. I. Flavonoids in Parinari. Brittonia 37: 169-178.

Cronquist, A. 1988. The evolution and classification of flowering plants, ed. 2. New York Botanical Garden, Bronx.

Cuatrecasas, J. 1950. Studies in South American plants III. Fieldiana, Bot. 27: 75-113.

Dahlgren, G. 1989. The last Dahgrenogram system of classification of the Dicotyledons. Pp 249-260. In: K. Tan, R.R. Mill \& T.S. Elias (eds.) Plant taxonomy phytogeography and related subjects: The Davis and Hedge Festschrift. Edinburgh University Press.

Dahlgren, R.M.T., 1980. A revised system of classification of the angiosperms. J. Linn. Soc., Bot. 80: 91-124.

Davis, CC \& M.W. Chase 2004. Elatinaceae are sister to Malpighiaceae; Peridiscaceae belongs to Saxifragales. Amer. J. Bot. 91: 262-273.

De Candolle, A. P., 1825. Rosaceae, in: Prodromus systematis naturalis regni vegetabilis 2: 525-639.

Desfontaines, R. 1819. Description de trois nouveaux genres de plantes: Diplophractum, Stylobasium, Chamelaucium. Mém. mus. Hist. Nat. 5: 34-44, 271-273.

Dissanayake, D. 1999. Phylogenetic research of the family Chrysobalanaceae. PhD. Thesis, University of Reading, UK.

Engler, A. 1905. Rosaceae africanae III. Bot. Jahrb. Syst. 36: 226.

Fay, M. F., K.M. Cameron, G.T. Prance, M.D. Lledo \& M.W. Chase 1997. Familial relationships of Rhabdodendron (Rhabdodendraceae): plastid rbcL sequences indicate a caryophyllid placement. Kew Bull. 52: 923-932.

Fernando, E.S., P.A. Gadek, D.M. Crayn \& C.J. Quinn. 1993. Rosid affinities of Surianaceae Molec. Phyl. Evol. 2: 344-350.

Focke, W. O. 1891. Rosaceae: Chrysobalanoideae. In: H.G.A. Engler, \& K. A. E. Prantl, Die natürlichen Pflanzenfamilien 3 (3): 55-60. Leipzig.

Fritsch, C. 1888. Ueber die Gattungen der Chrysobalanaceen. Verh. Zool.-Bot. Ges. Wien 38: 93-95.

Fritsch, C. 1899. Beitrage zur Kentniss der Chrysobalanaceen, I. Conspectus generis Licaniae. Ann. Naturhist. Mus. Wien 4: 33-60.

García-Villacorta, R., K.G. Dexter \& T Pennington. 2016. Amazonian white-sand forests show strong floristic links with surrounding oligotrophic habitats and the Guiana shield. Biotropica 48: 47-57.

Gilg, E. \& R. Pilger. Rutaceae in R. Pilger, 1905. Beiträge zur Flora der Hylea nach den Sammlungen von E. Ule. Verh. Bot. Vereins Prov. Brandenburg 47: 152-154.

Graham, R. A. 1960. Rosaceae, In Hubbard, C. E. \& E. Milne-Redhead (eds). Flora of Tropical East Africa, London, Crown Agents.

Grisebach, A.H.R, 1857. Systematische Untersuchungen über die Vegetation der Karaiben, insbesondere der Insel Guadeloup. Abh. Königl. Ges. Wiss. Göttingen 7: 50.

Hallier, H. 1903. Über die Verwandschafts-verhältnisse bei Englers Rosalen, Parietalen, Myrtifloren und in anderen Ordnungen der Dikotylen. Abh. Naturwiss. Verein Hamburg 18, 1: 1-98.

Hallier, H. 1923. Beitrage zur Kentnis der Linaceen (DC. 1819) Dumort, Beih. Bot. Centralbl. 21: 1-178.

Hooker, J. D. 1865. Rosaceae Chrysobalaneae. In: G. Bentham \& J. D. Hooker, Genera plantarum 1: 606609. London.

Hopkins, H.C.F., C.R. Huxley, C.M. Pannell, G.T. Prance \& F. White 1998. The biological monograph. Royal Botanic Gardens, Kew, Richmond, 236 pages.

Huber, J. 1909. Materiaes para a flora amazonica VII. Plantae Duckeanae austro-guyanenses. Bol. Mus. Paraense Hist. Nat. 5: 294-436.

Jeffers, J.N.R.1962. Principal component analysis of designed experiment. J. Roy. Statistical Soc., Ser. D, 12: 230-242.

Korthals, P.W. 1855. Chrysobalaneae. Ned. Kruidk. Arch. 3: 379-389.

Kostermans, A.J.G.H. 1965. The genus Acioa Aublet Rosaceae-Chrysobalanoideae in Malesia. Reinwardtia 7: 9-18.

Kostermans, A.J.G.H. 1969. Atuna Rafin versus Cyclandrophora Hassk. (Rosaceae - Chrysobalanoideae). Reinwardtia 7: 421-422.

Litt, A. \& M.W. Chase 1999. The systematic position of Euphronia, with comments of the position of Balanops: An analysis based on rbcL sequence data. Syst. Bot. 23: 21-19. 
Lleras, E. 1978. Monograph of Trigoniaceae. Flora Neotropica Monograph 19: 1-73. The New York Botanical Garden Press.

Mayo, S. J., R. Allkin \& 25 other authors, 2008. Alpha e-taxonomy: Responses from the systematics community to the biodiversity crisis. Kew Bull. 63 : 1-16.

Mildbraed, J. 1921. Afrolicania Mildbr. nov. gen. Eine neue Rosaceen-Gattung aus Westafrika. Notizbl. Bot. Gart. Berlin-Dahlem 7: 483-485.

Morton, J. F. 1981. Atlas of medicinal plants of Middle America, Bahamas to Yucatan. Thomas, Springfield, Mass.

Noreen, Y., G. Serrano, P. Perera \& L. Bohlin. 1999. Flavan-3-ols isolated from some medicinal plants inhibiting Cox-1 and Cox-2 cataysed prostaglandin biosynthesis. Pl. Med. 64: 520-524.

Ochoterena-Booth, H. \& H.F. Olvera 1992. Tzontzápotl: Licania platypus (Chrysobalanaceae) un recurso de potencial económico empleado desde el México prehispánico. Bull. Soc. Bot. México 52: 115-120.

Paracampo, N.E.N.P., G. T. Prance, R. J. Poppi, \& J. A. F da Silva. 2017. Chemotaxonomic study of Chrysobalanus icaco Linnaeus (Chrysobalanaceae) using ultra high performance liquid chromatography coupled with diode array detection fingerprint in combination with multivariate analysis. J. Separation Sci. 40(10): 2161-2169.

Paracampo, N.E.N.P., M do S. Padilha de Oliveira, G.T. Prance, R.J. Poppi \& J.A.F da Silva. 2020. Genetic fingerprinting of a Brazilian medicinal plant Chrysobalanus icaco L. (Chrysobalanaceae) Braz. J. Develop. 6(11): 86190-86202.

Pennington, T. D. 1990. Monograph of Sapotaceae. Flora Neotropica Monograph 52. The New York Botanical Garden, New York, 770 pages.

Pollard, B.J., C. A. Sothers \& G.T. Prance 2004. A new subspecies of Magnistipula Engl. (Chrysobalanaceae) from the Balimgemba Forest Reserve. Pp 51-53 In: V. Harvey, B. J. Pollard, I. Darbyshire, J.-M. Onana \& M. Cheek, The Plants of the Bali Ngemba Forest Reserve, Cameroon.

Prance, G. T. 1963. A taxonomic study of the Chrysobalanaceae. D. Phil Thesis, University of Oxford. Available on-line through the Bodleian Library. Oxford.

Prance, G. T. 1965. The Systematic Position of Stylobasium Desf. Bull. Jard. Bot. État. 35: 435-448. 1965.

Prance, G. T. 1966a. A Note on the Identity of the Genus Pleragina Arruda. Mem. New York Bot. Gard. 15: 133-135.

Prance, G. T. 1966b. Notes on the Chrysobalanaceae of Angola. Bol. Soc. Brot. ser. 2, 40: 181-186.

Prance, G. T. 1967. The taxonomy and ecology of the Chrysobalanaceae of the Amazon Basin. Atas do Simpósio sôbre a Biota Amazônica 4: 209-228.

Prance, G. T. 1968a. The systematic position of Rhabdodendron Gilg \& Pilg. Bull. Jard. Bot. État 38: 127146.

Prance, G. T. 1968b. Maranthes (Chrysobalanaceae), A new generic record for America. Brittonia 20: 203204.

Prance, G. T., D.J. Rogers \& F. White 1969. A taximetric study of an Angiosperm family: Generic delimitation in the Chrysobalanaceae. New Phytologist 68: 1203-1234.

Prance, G. T., 1973b. New and Interesting Chrysobalanaceae from Amazonia. Acta Amazonica 2(1): 7-16.

Prance, G. T., 1974a. Phytogeographic support for the theory of Pleistocene forest refuges in the Amazon Basin, based on evidence from distribution patterns in Caryocaraceae, Chrysobalanaceae, Dichapetalaceae and Lecythidaceae. Acta Amazonica 3(3): 5-28.

Prance, G. T., 1974b. Supplementary studies of American Chrysobalanaceae 3. Acta Amazonica 4(1): 17-23.

Prance, G. T., 1974c. A note on Couepia cognata (Steud.) Fritsch and related species (Chrysobalanaceae). Acta. Bot. Venez. 9: 119-122.

Prance, G. T., 1974d. A new Peruvian species of Chiropterophilous Couepia (Chrysobalanaceae). Brittonia 26: $302-304$.

Prance, G. T. 1975. The correct name for Castanha de cutia (Coupia edulis (Prance) Prance Chrysobalanaceae). Acta Amazonica 5(2): 39-41.

Prance, G. T., 1976a. Additions to Neotropical Chrysobalanaceae. Brittonia 28: 298-230.

Prance, G. T., \& A.R.A. Gorts van Rijn 1976. Chrysobalanaceae. In: J. Lanjouw \& A.L. Stoffers, Flora of Suriname. Vol. II Part 2. Additions \& Corrections: 524-555.

Prance, G. T. 1977. The Phytogeographic subdivisions of Amazonia and their influence on the selection of Biological Reserves. pp. 195-212. In: G.T. Prance, \& T.S. Elias (eds.) Extinction is Forever. New York Botanical Garden.

Prance, G. T. 1979a. New Genera and Species of Chrysobalanaceae from Malesia and Oceania. Brittonia 31(1): 79-95.

Prance, G. T., 1979b. Two new species of Chrysobalanaceae. Brittonia 31: 248-252. 
Prance, G. T., 1979c. The Taxonomy and Phytogeography of the Chrysobalanaceae of the Atlantic Coastal Forests of Brazil. Rev. Bras. Bot. 2: 19-39.

Prance, G. T., 1979d. Distribution patterns of lowland and Neotropical species with relation to history, dispersal and ecology, with special reference to Chrysobalanaceae, Caryocaraceae and Lecythidaceae. pp. 59-87. In: K. Larsen \& L.B. Holm-Nielsen (eds.) Tropical Botany. Academic Press.

Prance, G. T., \& F. White 1979. Resurrection of the genus Dactyladenia (Chrysobalanaceae). Brittonia 31: 483-487.

Prance, G. T., 1981. Notes on Couepia and Hirtella (Chrysobalanaceae). Brittonia 33: 347-356.

Prance, G. T., \& S. A. Mori. 1983.Dispersal and distribution of Lecythidaceae and Chrysobalanaceae. Sonderbd. Naturwiss. Vereins Hamburg 7: 163-186.

Prance, G. T., 1984. New taxa of Amazonian Chrysobalanaceae. Acta Amazonica 13: 21-30.

Prance, G. T., 1985a. A new combination in Maranthes (Chrysobalanaceae). Brittonia 37: 76-77.

Prance, G. T., 1985b. Monographing in the 1980's. Aliso 11(2): 231-242.

Prance, G. T., 1986. Studies on the flora of the Guianas 19. New taxa of Chrysobalanaceae for the Flora of the Guianas. Proc. Kon. Ned. Akad. Wetensch. C. 89: 111-116.

Prance, G. T., 1987. Notulae de Chrysobalanacis Malesianis Praecursoriae. Brittonia 39: 364-370.

Prance, G. T., \& F. White 1988. The genera of Chrysobalanaceae: a study in practical and theoretical taxonomy and its relevance to evolutionary biology. Philos. Trans., Ser. B 320: 1-184.

Prance, G. T., 1988. Padrões de distribuição e especiação em Chrysobalanaceae e outras famílias de plantas Amazônicas. Acta Bot. Bras. 1 (2), Supl.: 1-25.

Prance, G. T., 1990a. Consensus for conservation. Nature 345: 384. 1990.

Prance, G. T., 1990b. Bassett Maguire and the Chrysobalanaceae connection. Mem. New York Bot. Gard. 64: 197-201.

Prance, G. T., 1991. Two new species of Chrysobalanaceae. Kew Bull. 46: 105-109.

Prance, G. T., 1992a. Ant association with Parinari excelsa (Chrysobalanaceae) in Marajó, Brazil. Biotropica 24: $102-104$.

Prance, G. T., 1992b. Five new species of neotropical Chrysobalanaceae. Kew Bull. 47: 247-256.

Prance, G. T., 1992c. New species and new records of neotropical Chrysobalanaceae. Kew Bull. 47: $633-646$.

Prance, G. T., 1992d. The phytogeography of savanna species of neotropical Chrysobalanaceae. pp. 295-330. In: P.A. Furley, J. Procter and J.A. Ratter (eds.). Nature and dynamics of forest-savanna boundaries. Chapman Hall.

Prance, G. T., 1993. Licania hedbergii (Chrysobalanaceae): a new species for the highlands of Ecuador. Opera Bot. 121: 279-280.

Prance, G. T., 1994a. The use of phytogeographic data for conservation planning. pp. 145-163. In: P.L. Forey, C.J. Humphries and R.I. Vane-Wright (eds.) Systematics and Conservation Evaluation. Clarendon Press, Oxford.

Prance, G. T., 1994b. Two new species of neotropical Chrysobalanaceae. Kew Bull. 49: 359-363.

Prance, G. T., 1995a. Two new species of Licania (Chrysobalanaceae) Kew Bull. 50: 141-145.

Prance, G. T., 1995b. New taxa and notes on neotropical Chrysobalanaceae. Kew Bull. 50: 707-721.

Prance, G. T., 1995c. Chrysobalanaceae. The World of Plants Encyclopaedia. Asahi Shimbun Press 58: 5315-316.

Prance, G. T., 1998. Atuna pp. 90-92; Licania pp. 328-329; Maranthes pp. 356-357; Parastemon pp. 427428; Parinari pp. 428-430 In: M.S.M. Sosef, L.T. Hong \& S. Prawirohatmodjo (eds.). Plant Resources of South-East Asia 5(3): Timber Trees: Lesser known timbers. Prosea.

Prance, G. T., 1999. New species and notes on Neotropical Chrysobalanaceae. Kew Bull. 54: 103-115.

Prance, 1999. A new species of Hirtella L. (Chrysobalanaceae) from Ecuador. Kew Bull. 54: 995-997.

Prance, G. T., 2001a. Two new species of Licania (Chrysobalanaceae). Novon 11:325-328.

Prance, G. T., 2001b. A new species of Kostermanthus (Chrysobalanaceae) from Sarawak, Malaysia. Novon 11:451-453.2001.

Prance, G. T., 2002a. Rhabdodendraceae. Pp. 339-341 In: K. Kubitzki \& C. Bayer (eds.) The families and genera of vascular plants. Springer.

Prance, G. T., 2002b. New combinations in African Chrysobalanaceae. Kew Bull. 57: 993-995.

Prance, G. T., 2004a.Chrysobalanaceae. pp. 100-102. In: N. Smith, S. A. Mori et al. (eds.). Flowering plants of the Neotropics.

Prance, G. T., White 2004b. The uses of Atuna racemosa Raf. (Chrysobalanaceae) in Samoa. Econ. Bot. 58: 470-475.2004.

Prance, G. T., 2005. Ethnobotany of the family Chrysobalanaceae. Ethnobot. 17: 13-19.

Prance, G. T., 2007. Chrysobalanaceae. Flora da Reserva Ducke, Amazonas, Brazil. Rodriguesia 58: $493-531$. 
Prance, G. T., 2008c. Atuna racemosa Rafin (Chrysobalanaceae). pp. 1-5 In: K. V. Peter (ed.) Underutilized and Underexploited Crops Vol 3.

Prance, G. T., 2011. Monography and biodiversity studies. Pp15-24, In T. Stuessy \& W. Lack (eds.) Monographic plant systematics: Fundamental assessment of plant biodiversity. Regnum Vegetabile 153.

Prance, G. T., 2013. A new species of Licania (Chrysobalanaceae) from Cordillera del Cóndor, Ecuador. Phytokeys 26: 71-74.

Prance, G. T., 2014a. Chrysobalanaceae. pp. 1931-232. In: K. Kubitzki (ed.). The Families and genera of vascular plants. Vol 11.

Prance, G. T., 2014b. Three new species of Licania (Chrysobalanaceae) from Peru. Phytokeys 42: 1-10.

Prance, G. T., 2014c. That glorious forest: Exploring the plants and their indigenous uses in Amazonia. The New York Botanical Garden Press, 214 pages.

Prance, G. T., 2017. Two new species of Licania (Chrysobalanaceae) from the Mata Atlantica of eastern Brazil. Kew Bull. 72 (3): 43.

Prance, G. T., 2019. The correct name for Atuna excelsa (Chrysobalanaceae), Gard. Bull. Singapore 71: 8788.

Puff, C. \& A. Weber 1976. Contributions to the morphology, anatomy, and karyology of Rhabdodendron, and a reconsideration of the systematic position of the Rhabdodendraceae. Pl. Syst. Evol. 125: 195-222.

Rogers, D. J., H.S. Fleming \& G.F. Estabrook 1967. Use of computers in studies of taxonomy and evolution. In: Th. Dobzhansky, M.K. Hecht \& W. C. Steere (eds.) Evolutionary Biology: 169. New York.

Rubin, J. 1967. Optimal classification into groups: an approach for solving the taxonomy problem. J. Theor. Biol. 15: 103.

Sagot, P.A. 1883. Catalogue des plantes phanérogames et cryptogames vasculaires de la Guyane français. Ann. Sci. Nat. Bot., sér. VI, 15: 303-336.

Small, J.K. 1913. Flora of Miami, New York., published by the author.

Soltis, D. E, P.S. Soltis \& 13 other authors. 2000. Angiosperm phylogeny inferred from 18S rDNA, rbcL, and atpB sequences. J. Linn. Soc., Bot. 133: 381-461.

Soltis, D. E, P.S. Soltis, P. K. Endress \& M.W. Chase 2005. Phylogeny and evolution of Angiosperms. Sinauer Associates, Sunderland Massachusetts.

Sothers, C.A., G.T. Prance, S. Buerki, R de Kok \& M. Chase. 2014. Taxonomic novelties in Neotropical Chrysobalanaceae: towards a monophyletic Couepia. Phytotaxa 172(2): 176-200.

Sothers, C.A. \& G. T. Prance 2014. Ressurection of Angelesia, a southeast Asian genus of Chrysobalanaceae. Blumea 59: 103-105.

Sothers, C.A., G.T. Prance \& M. W. Chase 2016. Towards a monophyletic Licania: a new generic classification of the polyphletic Neotropical genus Licania (Chrysobalanaceae). Kew Bull. 71 (4):1-68.

Sothers, C.A., G.T. Prance \& M. W. Chase 2019. A new name in Moquilea (Chrysobalanaceae). Kew Bull. 74: 54.

Takhtajan, A. 1969. Flowering plants origin and dispersal. Oliver \& Boyd, Edinburgh.

Takhtajan, A. 1996. Diversity and classification of flowering plants. Columbia University Press, New York.

Thorne, R. F. 1992. Classification and geography of the flowering plants. Bot. Rev. 58: 225-348.

Tiffney, B.H., J.G. Fleagle \& T.M. Brown 1994. Early to Middle Miocene angiosperm fruits and seeds from Fejej, Ethiopia. Tertiary Research 15: 25-42.

Vargas, C. E., M.F. Mendes, D.A. Azevedo, F.L.P. Pessoa \& A.C. Uller 2010. Extraction of the essential oil of abajeru (Chrysobalanus icaco) using supercritical CO2. J. Supercrit. Fluids 54: 171-177.

White, F. 1976. The taxonomy, ecology and chorology of African Chrysobalanaceae (excluding Acioa). Bull. Jard. Bot. État 43: 265-350.

Williams, P.H. 1993. Measuring more of biodiversity for choosing conservation areas, using taxonomic relatedness. Pp 194-227 in: Y-Y Moon (ed). International Symposium on Biodiversity and Conservation. Seoul, Korea University.

Williams, P.H., D.W. Gibbons, C.R. Margules, A.G. Rebelo, C.J. Humphries \& R.L. Pressey, 1996a. A comparison of richness hotspots and complementary areas for conserving biodiversity of British birds. Conservation Biology 10: 155-174.

Williams, P.H., G.T. Prance, C.J. Humphries and K.S. Edwards 1996b. Promise and problems of applying quantitative complementary areas for representing the diversity of some Neotropical plants (families Dichapetalaceae, Lecythidaceae, Caryocaraceae, Chrysobalanaceae and Proteaceae). J. Linn. Soc., Biol. 58: $125-157$.

Williams, W. T. \& G. N. Lance, 1958. Automatic subdivision of associated populations. Nature 182: 1755.

Williams, W. T. \& J.M. Lambert 1959. Multivariate methods in plant ecology: I Association-Analysis in plant communities. J. Ecol. 47: 83-101. 
Williams, W. T. \& J.M. Lambert 1960. Multivariate methods in plant ecology II. The use of an electronic digital computer for association-analysis. J. Ecol. 48: 689-710.

Wirth, M., Estabrook, G. F. \& D. J. Rogers. 1966. A graph theory model for systematic biology, with an example for the Oncidiinae (Orchidaceae). Syst. Zool. 15: 59-69.

Yakandawala, D., C.M. Morton \& G. T. Prance. 2001. A phylogenetic study of the Chrysobalanaceae using morphological data. Ceylon J. Sci. (Biol.) 28: 1-17.

Yakandawala, D., C.M. Morton \& G. T. Prance 2010. Phylogenetic relationships of the Chrysobalanaceae inferred from chloroplast, nuclear and morphological data. Ann. Missouri Bot. Gard. 97: 259-281. 